\title{
Inside the Black Box: Bank Credit Allocation in China's Private Sector
}

\author{
Michael Firth ${ }^{\mathrm{a}^{*}}$, Chen Lin $^{\mathrm{b}}$, Ping Liu ${ }^{\mathrm{a}}$ and Sonia M.L. Wong ${ }^{\mathrm{a}}$ \\ ${ }^{a}$ Department of Finance and Insurance, Lingnan University, Hong Kong \\ ${ }^{b}$ Department of Economics and Finance, City University of Hong Kong
}

November, 2008

\begin{abstract}
Allen, Qian and Qian (2005, Journal of Financial Economics) explores the role of alternative financing channels (e.g., trade credits and private credit agencies) and governance mechanisms, such as those based on reputation and relationship, in explaining the growth of the private sector in China. We complement their study by examining how the Chinese state-owned banks allocate loans to private firms. We find that the banks extend loans to financially healthier and better-governed firms, which implies that the banks use commercial judgments in this segment of the market and are behaving more like their western counterparts. On top of this, however, we find that having a state minority ownership helps firms obtain bank loans, which suggest that political connections still play a role in gaining access to bank finance. In addition, we find that commercial judgments are important determinants of the lending decisions for manufacturing firms, large firms, and firms located in regions with a more developed banking sector; political connections are important for firms in service industries, large firms, and firms located in areas with a less developed banking sector.
\end{abstract}

JEL classification: G20; G21; G30

\footnotetext{
${ }^{2}$ We thank the Enterprise Surveys Center at the World Bank for providing the dataset used in this study. We thank Ping Lin and Shang-jin Wei for helpful discussions and comments. Financial support from Lingnan University (DR07B2) is greatly acknowledged.

* Corresponding author. Tel: (852)26168950; fax: (852) 24621073; E-mail address: mafirth@ln.edu.hk.
} 


\section{Inside the Black Box: Bank Credit Allocation in China's Private Sector}

\section{Introduction}

China's transition from a centrally planned socialist economy to a vibrant and fast expanding commercially oriented economy is well-documented (Allen, Qian and Qian, 2005; Lardy, 1998). This transformation involves moves toward the adoption of free-market policies, improvements in the commercial banking system, developing modern financial markets, and the writing and enforcement of commercial laws. At the corporate level, the reorganization of wholly owned state enterprises into listed joint stock companies with minority private ownership has led to some improvement in efficiency (Chen, Firth, Xin and $\mathrm{Xu}, 2008)$. However, the biggest spark for economic growth has been the emergence of privately owned non-listed firms. According to the National Bureau of Statistics, the private sector accounted for roughly $50 \%$ of GNP in 2005 and this is expected to rise to at least $75 \%$ by $2010^{1}$.

One interesting, and as yet unresolved, question is the role that the banking sector has played in helping finance the expansion of private firms. The focus of our study, therefore, is to shed some light on this issue and, in particular, to gain an understanding of how banks make lending decisions to non-listed private businesses. Our interest in this issue is piqued by the seemingly mixed messages from prior research.

International evidence provides some background on the conditions that are deemed necessary for economies to flourish. La Porta, Lopez-de-Silanes, Shleifer and Vishny (1997, 1999, 2000, 2002a), in a series of studies, argue that the rule of law (including law enforcement), private ownership, and corporate governance are crucial elements in explaining economic success and corporate value. Other studies have stressed the need for highly developed capital markets and financial intermediaries to help foster a successful corporate sector (King and Levine, 1993; Rajan and Zingales, 1998; Kroszner, Laeven and Klingerbiel, 2007). Using this "law-finance-growth" research (Demirgüç-Kunt and Maksimovic, 1998) as

\footnotetext{
${ }^{1}$ http://www.chinadaily.com.cn/china/2006-09/22/content_694432.htm
} 
a backdrop, Allen et al. (2005) conclude that China does not display the conditions necessary for a vibrant private sector. For example, it is argued that despite some recent improvements, China still has an underdeveloped and capricious legal system, weak investor protection, a chronic lack of law enforcement, rampant cronyism, and overarching government interference and control. This suggests that China's private sector should be subdued at best and completely irrelevant at worst, but this clearly flies in the face of the available evidence ${ }^{2}$. Allen et al. (2005) seek to explain the paradox by arguing that private firms make use of informal financing channels such as trade credits and private credit agencies that rely on alternative governance mechanisms such as family connections and the personal reputation of the entrepreneurs. By implication, banks do not play an active role in financing private firms in China. However, international evidence has shown that the support of formal financing to private firms determines the sustainability of this sector (Beck and Demirgüç-Kunt, 2006) and informal financing based on relationships is detrimental to business exchange, competition and innovation (Biggs and Shah, 2006). Thus, the importance of informal finance, especially in the longer-term, is a controversial topic and one that deserves additional investigation. In this study, we focus on the formal financing and governance mechanisms of non-listed private Chinese firms using survey data from the World Bank.

There are numerous criticisms of China's banking system including factors that inhibit it from providing finance to the private sector. These include the stylized facts that the banks are state-controlled (almost 100\% owned by the government during the period of our study $)^{3}$, carry out policy lending that follows government directives rather than commercial considerations, and discriminate against private firms (Brandt and Li, 2003; Cull and Xu, 2003). As support for the latter stylized fact, bank statistics show that although the private sector accounts for 50 percent of the economy it accounts for just 7 percent of bank lending. In light of these and other criticisms, the Chinese government has introduced a series of reforms in the banking sector to promote the availability of bank loans to private firms.

\footnotetext{
${ }^{2}$ In this sense, China has been regarded as a significant counter-example to the findings of the existing literature on law, institutions, finance and growth (Allen et al., 2005).

${ }^{3}$ According to La Porta, Lopez-de-Silanes and Shleifer (2002b), the government owns $99.45 \%$ of the ten largest banks in China.
} 
However, systematic evidence on how bank loans are allocated to private firms in China remains scarce. Based on a World Bank nation-wide survey, this paper attempts to look inside the black box of bank lending decisions and answer the following questions about the determinants of bank financing to the private sector. Do the banks allocate loans to private firms according to a firm's financial performance? Do political connections still matter in the allocation of loans to the private sector? Does managerial experience and corporate governance facilitate private firms' access to bank loans? Do the determinants of lending decisions vary with industries, firm size and level of market development?

We find that banks tend to allocate loans to private non-listed firms with higher profitability, more experienced and incentive-compatible CEOs, and more independent corporate boards. The results suggest that the banks are extending loans to financially healthier firms and better governed firms. As a complement to the conclusions in Allen et al. (2005) regarding the importance of informal channels of finance, we present evidence that the banking sector uses commercial judgments in lending decisions. However, we find that state ownership and business connections with the government still help firms gain access to bank finance. Thus, political connections do carry weight in the lending decisions to the private sector. Further analyses reveal that the determinants of the lending decisions vary across industries, firm size and levels of institutional development. Specifically, commercial judgments are important determinants of the lending decisions for manufacturing firms, large firms, and firms located in regions with a more liberalized banking sector. Political connections are important for firms in service industries, large firms, and firms located in areas with a less liberalized banking sector. Our results indicate that, after 30 years of reform, China's banking sector has started to behave more like commercially viable corporate banks. We find that the influences of political connections still persist, although the weaker role of political connections in regions with a more liberalized banking sector suggests that the banks are becoming more and more market-oriented as the reforms take effect. Our findings add to the recent literature on the structure, performance and functioning of China's banking sector (e.g. Berger, Hasan and Zou, 2009; Ferri, 2009; Fu and Heffernan, 2009; Lin and Zhang, 2009; Wu and Yue, 2009; Jia, 2009). 
This paper is structured as follows. Section 2 discusses the research background. Section 3 describes the data and the empirical models. The empirical results and their interpretations are reported in section 4 . Section 5 concludes.

\section{Institutional Background}

\subsection{The development of the Chinese private sector}

One of the most far-reaching changes in China's economy brought about by the economic reforms is the gradual shift away from complete reliance on state-owned and collective enterprises to a mixed economy where private enterprises play a major role in promoting growth, innovation, and employment. The private sector, which consists of mainly small and medium sized enterprises (SMEs hereafter), is considered rightly as the major engine of China's rapid growth.

Public ownership is regarded as a defining feature of socialism. The rise of China's private sector reflects the government's compromise between ideological correctness and economic pragmatism. The $15^{\text {th }}$ Congress of the Chinese Communist Party in September 1997 lifted many legal and economic barriers to private sector growth, including giving official approval to bank lending to private business. Nevertheless, towards the end of the 1990s, private ownership was still considered an inferior ownership arrangement and thus operated under an adverse political and legal environment.

Since the late 1990s, there has been a dramatic change in sentiment towards private capital. This follows the Communist party's belated acknowledgement of the informal private sector's importance and relevance to the national economy (Tsai, 2007). Moreover, recent government personnel reform and fiscal reform also provide a more supportive business environment for the private sector (Allen et al., 2005). In 2004, the National Congress approved a constitutional amendment to protect private property rights, granting "private property" an equal legal status to "public property". Despite the constitutional changes and official encouragement of the private sector, some commentators continue to believe that the government's ownership of formal external financing sources inevitably leads to a biased capital allocation policy that discriminates against private businesses (Brandt and Li, 2003; Ge and Qiu, 2007). 
The economic reforms have reduced significantly the size of the state sector in the economy, with non-state enterprises' production to total production increasing from $50.37 \%$ in 1998 to $66.72 \%$ in 2005 . The proportion of total employment provided by private firms increased from $58.1 \%$ to $76.26 \%$ in the same period (see Table 1). Table 1 presents official statistics that show the rapid growth of the economy and the even faster growth of the private sector. The decline of the state sector in China is supposed to emancipate the banking sector from the obligation to provide policy loans to the ailing state-owned enterprises. ${ }^{4}$ As we shall discuss shortly, a series of reforms have been introduced with the objective of transforming China's banking sector from a conduit of government policies into a fully commercialized modern financial intermediary that channels funds to the most efficient economic units regardless of their ownership identity (Podpiera, 2006). As a result, and local political influence notwithstanding, the reforms have led to significant changes in the lending behaviors of the commercial banks in China (Park and Shen, 2003). Next, we briefly review China's banking sector reforms in order to justify the variable selection of our model and to provide further institutional background for our study.

\section{[Table 1 Here]}

\subsection{The evolving status of the Chinese banking sector}

A salient characteristic of China's banking sector is the dominant state ownership of banks, which allows government involvement in the decision making of those banks. ${ }^{5}$ Before the late 1990s, the Chinese banking sector had little latitude but to serve as a conduit for channeling low-cost capital to SOEs because SOEs were assumed the task of employment and social welfare provision. The private sector was virtually excluded from the formal credit market. As a result, policy lending remained a defining characteristic of the Chinese banking system $^{6}$. Serving as policy lending tools, the state-owned banks were able to ignore the non-

\footnotetext{
${ }^{4}$ Of course, the problem of non performing loans continues to exist although there are plans to hive these off to specialist agencies.

${ }^{5}$ Sapienza (2004), Dinc (2005), and La Porta et al. (2002b) also discuss problems associated with state ownership of banks and how these problems distort commercial lending decisions. Our study extends this strand of literature by providing evidence from China.

${ }^{6}$ According to Lardy (1998), even when narrowly defining policy lending as loans for specific projects identified by State Planning Commission, one-third of total loans outstanding were policy loans in 1985, while it was one fifth in 1995. If loans for other projects and for bailouts are included in the definition, then policy lending was much higher.
} 
performing loans and bank profitability on the grounds that they were caused by their stateassigned credit obligations and therefore it was up to the central government to bear the final responsibility. Accordingly, the banks in China had neither the incentives nor the ability to screen borrowers and ensure loan repayment.

As a consequence of this policy lending, banks in China have been saddled with extensive portfolios of non-performing loans (NPLs). According to Dai Xianglong, governor of the People's Bank of China (the defacto central bank), NPLs as a share of state banks' total loans was $20 \%$ in 1994 . The ratio increased to $25 \%$ in 1997 and then $35 \%$ in 2000 (Tung, 2002). However, these estimates are based on a loan classification system that is more lenient than the systems adopted in most modern capitalist banking systems. The estimates of western observers generally put the NPL ratio as high as 40 to 50 per cent of loans outstanding. ${ }^{7}$

The declining asset quality of state-owned banks imposed a heavy tax burden as the government was forced to inject public funds to clean up the banks' balance sheets. This injection of public funds has been very visible in the last few years as banks have sought to shore up their balance sheets prior to listing on foreign as well as domestic stock markets. What is more, China's government is very concerned about the competitiveness of domestic banks, as the country has begun to open the banking sector to foreign competitors since the end of 2006, as mandated by the World Trade Organization (WTO). In light of the problems and the international competition they face, the state owned banks have introduced reforms on five fronts: devolving the policy lending task to three policy banks, transferring NPLs to newly established asset management companies, internal management reforms, introducing strategic investors, and public listing ${ }^{8}$, all of which are aimed at transforming the banks from a policy tool into a business entity operating on a commercial basis. The ongoing commercialization process of China's banking sector affects the behavior of bank executives. Recently introduced incentive and discipline mechanisms precipitated improved credit

\footnotetext{
${ }^{7}$ Lardy (1998, pp. 115-124).

${ }^{8}$ Note, at the time of the survey (2003), all banks were fully owned by the state.
} 
analysis and risk evaluation by China's banks. ${ }^{9}$ Moreover, local governments no longer have direct authority over local branches of banks. The performance of local bank staff is evaluated by branches higher up in the hierarchy of the bank, thereby limiting local political influence on bank decisions.

Faced with the increasing importance of the private sector in employment creation and economic growth, the government in 1997, for the first time, formally allowed banks to extend loans to the private sector. Recently, the government has also introduced a series of measures to promote the availability of bank loans to SMEs. Banks were urged to base their lending decisions not on the size and ownership structure of the borrowers, but on the default risks and business prospects of the eligible borrowers. ${ }^{10}$

Asymmetric information problems are particularly pervasive in the lender-borrower relationship in China. After serving as a key government policy tool for decades, the banks simply do not have the credit history records to back up their loan allocation decisions (Wong and Wong, 2001) ${ }^{11}$. The information problems are particularly severe when lending to the private sector because the private firms are new customers to the banks (which had previously lent only to SOEs). With a short bank-borrower relationship, the banks are not able to accumulate sufficient soft qualitative information on private firms (Petersen and Rajan, 1994; Stein, 2002). Most private firms in China are SMEs and less is known about them because of their informal accounting, internal control and governance systems (Berger and Udell, 2006).

It is crucial that Chinese banks find signals or indicators to infer the quality of the potential borrowers. Based on the extant literature, financial performance, political connection, and corporate governance have the potential to serve as credible signals (e.g., Mitton, 2002; Dinc, 2005; Khwaja and Mian, 2005). Identification of the signals used by

\footnotetext{
${ }^{9}$ The growing importance of performance-based payments in banking staffs' compensation packages results in more weight being attached to bank profitability. In July 2004, the China Banking Regulatory Commission (CBRC) promulgated the Guidelines on Commercial Banks' Due Diligence Performance in Credit Business, which requires each bank to define clearly the responsibilities and due diligence assessment criteria for every function involved in the lending process. In a more general setting, Firth, Fung and Rui (2006) show that listed firms in China are using performance as a factor in setting the compensation of senior executives.

${ }^{10} \mathrm{http}: / /$ www.cbrc.gov.cn/english/home/jsp/docView.jsp?docID $=1250$

${ }^{11}$ Such information sharing is very helpful to banks when making lending decisions on SMEs (Pagano and Jappelli, 1993; Miller, 2003).
} 
banks in the screening process will provide valuable insights into the important question as to whether banks are operating on a commercial basis or are bedeviled by political interference. By examining the role of formal financing in private sector growth, we can develop better insights into the sustainability of the private sector as the engine of China's economic expansion.

\section{Sample and Variables}

\subsection{Sample}

Most data used in this study come from the business environment and enterprise performance survey conducted jointly by the World Bank and the Enterprise Survey Organization of China in early 2003. To achieve a balanced representation of enterprises, the sample includes about 2,400 enterprises from the following 18 cities across five regions in China: (1) the Central Region: Changsha, Nanchang, Wuhan, and Zhengzhou; (2) the Northeast Region: Benxi, Changchun, Dalian, and Harbin; (3) the Northwest Region: Lanzhou and Xi'an; (4) the Southwest Region: Chongqing, Guiyang, Kunming, and Nanning; and (5) the Coastal Area: Hangzhou, Jiangmen, Shenzhen, and Wenzhou (for a review of the survey, see Lin, Lin and Song, 2008). Thirteen of the cities are provincial capitals, while the remaining five are major industrial cities. The survey includes firms with different ownership structures and different sizes. We focus on private firms. An enterprise is classified as a private firm if the percentage of the shares owned by the private sector is more than $50 \%$. Based on this criterion, there are 1,868 firms in our sample. Furthermore, the survey is sampled from 5 manufacturing industries and 5 service industries. ${ }^{12}$

The survey has two main parts. Part one consists of managers' responses to questions on general information about the firm, management, innovation, market environment, relationships with clients and suppliers, location of manufacturing plant, relations with government, and international trade. Part two is quantitative information on production, costs, employee training, schooling, and wages (based on interviews with the firm's accountant and

\footnotetext{
${ }^{12}$ Manufacturing: apparel and leather goods, electronic equipment, electronic components, consumer products, and vehicles and vehicle parts; Services: accounting and related services, advertising and marketing, business logistics services, communication services, and information technology services.
} 
personnel manager). The qualitative questions pertained only to the year 2002 and so we use this as the year of our study.

\subsection{Modeling the lending decision}

To develop a successful commercial lending operation, banks need to set in place criteria for evaluating credit risk and deciding the amount of the loans. However, these criteria are not observable to the outside world. Even if we have access to a bank's official policies on lending we would still be missing the subjective judgments made by the credit officers. We seek to explore inside the black box of lending decisions by testing whether certain criteria are associated with the lending decision and the loan amount. These criteria include the profitability of the prospective borrower, the experience and incentives of the top managers of the borrower, and the governance (board structure) of the borrower. Furthermore, we also examine whether the political connections of the borrower are a factor in lending decisions.

We develop the following model to help explain the access to bank finance and the amount of the loan.

$$
\begin{aligned}
& \text { BANKING_FINANCE }_{i 2002}=\mathrm{f}\left(\beta_{0}+\beta_{1} \text { FIRM PERFORMANCE } E_{i}+\beta_{2} \text { POLITICALCONNECTION }_{i}\right. \\
& \left.+\beta_{3} \text { CORPORATE GOVERNANCE }{ }_{i}+\beta_{4} \text { OTHERCONTROLS } S_{i}+\beta_{5} \text { INDUSTRY }_{i}+\varepsilon_{i}\right)
\end{aligned}
$$

Information on access to loans and the amount of loan is taken from the responses to the survey questions. ${ }^{13}$ The independent variables are the performance of the firm, managerial experience and incentives, political connections, governance, and a set of controls. The independent variables, which are described in detail below, are constrained by the questions asked in the survey. We use probit models for specifications where access to bank finance is the dependent variable, and use tobit models for those where the size of the bank loan scaled by total assets is the dependent variable (to take into account the fact that the loan size is censored at zero).

\subsection{Variables}

Detailed definitions of the variables used in the regressions are shown in Table 2, while Table 3 shows the summary statistics.

\footnotetext{
${ }^{13}$ Note, we use a sample of private non-listed firms and so there are no publicly available financial statements to extract or check data.
} 
[Tables 2 and 3 Here]

\subsubsection{BANKING_FINANCE}

We use two different variables to capture BANKING_FINANCE. Access to Banking Finance is a dummy variable that equals one if a firm's answer to the question "Do you have a loan from a bank or financial institution?" is "Yes", and zero otherwise. The second variable, Size of Banking Finance, is the amount of the line of credit reported by the managers scaled by the firm's total assets. About $22 \%$ of firms disclose that they have a bank loan and the mean loan is $4.66 \%$ of the total assets.

\subsubsection{FIRM PERFORMANCE}

At the time of the survey (2003), China's banking system lacked consolidated interbank information sharing on client companies and there was no nation-wide credit rating system. Each bank has its own individual information system and way of doing business (Dobson and Kashyap, 2006). Banks resort to using the prospective borrowers' accounting statements to make informed inferences about financial condition. We use Lagged ROS as our prime measure of FIRM_PERFORMANCE. Lagged Return on Sales (Lagged ROS) is the one year lagged EBIT (Earnings before Interest and Taxes) divided by total sales ${ }^{14}$. EBIT is used as it represents core earnings and is less likely to have been manipulated. In contrast, net income is often confounded by earnings management and the gains and losses from arbitrary intra-group asset sales (non-core earnings). Furthermore, discussions with bankers suggest than operating income is used in evaluating whether to lend to a private firm. The mean (median) Lagged Return on Sales is 0.106 (0.102).

\subsubsection{POLITICAL CONNECTION}

Political connections, in its broadest scope, may have a favorable effect on bank lending decisions (Khwaja and Mian, 2005; Faccio, Masulis and McConnell, 2005). The survey database has three variables that represent different facets of political connections and we use these in our model. State Minority Ownership is a dummy variable, which is equal to one if the private firms have a state minority shareholding. CEO Government Official is a

\footnotetext{
${ }^{14}$ We also used Lagged Return on Assets as an alternative performance measure. The empirical results are very robust. Although we use both measures, scaling by sales is better than scaling by assets because the values placed on assets are sometimes arbitrary.
} 
dummy variable that is equal to one if the general manager (this is the CEO in U.S. parlance) was a government official before taking a position in the enterprise, and zero otherwise. This variable represents cases where the firm might find it easier to borrow because the CEO has a former connection with the government. The dummy variable Business Connection is equal to one if the firm has business transactions with the government or its affiliates, and zero otherwise. It should be noted that lending based on State Ownership and Business Connection might not be motivated purely by political considerations and biases. Banks might lend more to private firms with state ownership and business connections with the government because the banks have more information on these firms. Furthermore, firms with state ownership and business relations with governments are more likely to get help from governments in time of financial difficulties and thus may be less risky for the banks.

It is apparent from our dataset that many of the private firms have some sort of relations with the government. $3 \%$ of private firms have state minority ownership and $22 \%$ of them have business relations with the government or its affiliates. However, the ability of the private sector to extract economic benefits from former political connections may be limited as only $5.3 \%$ of CEOs of private firms are former government officials.

\subsubsection{CORPORATE GOVERNANCE}

The quality of a firm's corporate governance should be a concern for banks as they make decisions on whether to extend credit. This is because good corporate governance can help reduce credit risks by mitigating the agency problems between shareholders and managers and also by improving corporate transparency and the quality of financial information (Shleifer and Vishny 1997; Firth, Fung and Rui, 2007). Consistent with theoretical predictions, Anderson, Mansi and Reeb (2004) offer evidence that more independent and active boards are associated with a lower cost of debt financing for U.S. firms. Ashbaugh-Skaife, Collins and LaFond (2006) also find that stronger corporate governance increases a firm's probability of receiving an investment-grade credit rating. Bhojraj and Sengupta (2003) find that firms with greater institutional ownership and more independent boards enjoy lower bond yields and higher ratings in their new debt issues, and Graham, Li and Qiu (2008) show that corporate misreporting is associated with tighter bank 
loan contracts including higher spreads, shorter maturities, higher likelihood of being secured and more covenant restrictions. Chava, Livdan and Purnanandam (2008), however, find that stronger shareholder rights (as measured by fewer takeover defenses) is associated with costlier bank loans because of the potential conflicts of interests between shareholders and bondholders in takeovers. Complementing the above U.S. studies, we examine whether the banks in a large emerging market, China, also take the corporate governance of private firms into account when they evaluate their loan applications.

Utilizing the data provided by the survey, we construct two sets of corporate governance variables. The first set is related to managerial experience and incentive contracts. Managerial incentive contracts can alleviate moral hazard problems, reduce agency costs, induce managers to maximize firm value and thus reduce the credit default risk (Cull and $\mathrm{Xu}$, 2003). Overall, the existence of incentive contracts and the CEO's work experience provide information about management's motivations and abilities and thus signals a firm's quality. We use three salient characteristics of the CEO in our model. CEO Experience is the number of years the CEO has held the top management position at the firm or with previous firms. Banks may place more trust in those firms whose CEOs have substantial top management experience. The mean (median) value for experience is 6.7 years (6 years), although there is considerable variability across firms as shown by the standard deviation of 4.7 years. Managerial Ownership takes the value of one if the manager's response to the question of "Does the general manager own company stocks?" is affirmative and zero otherwise. Annual Salary System is a dummy variable that takes the value of one if the annual salary system is adopted and zero otherwise ${ }^{15}$. Incentive contracts and stock ownership provide incentives to make the CEO work harder and act as a kind of intangible collateral in the eyes of the lenders

\footnotetext{
${ }^{15}$ In recent years, the "annual salary system" (Nianxinzhi) has become increasingly popular because the central government has gradually recognized that compensation structure is one of the key elements in enhancing enterprise productivity and efficiency. In November 2003, the State Asset Management Bureau (SAMB), in an effort to further the wage reform, issued a circular to implement formally the incentive-based annual salary system in 189 SOEs directly owned by the central government. According to the circular, managerial compensation in the "annual salary system" consists of two major parts: fixed base salary and performance salary. This is very similar to the "salary plus bonus" compensation package offered by firms in developed market economies. In addition to the largest SOEs, the annual salary system has also been widely adopted by the private non-listed firms.
} 
(Jensen and Meckling, 1976). We therefore expect positive coefficients on these variables. Table 3 shows that 36 percent of CEOs have an ownership interest in the firm they manage. More than 20 percent of firms have incentive pay systems for the CEO.

The second set of corporate governance variables is related to the salient characteristics of the board. The board of directors monitors managers on behalf of the shareholders and if they are effective in their duties, they should deter wealth destroying or other wanton behavior of the CEO and top management. Other stakeholders, including lenders, should benefit from this monitoring. We capture board effectiveness with three variables. Board Ownership is the percentage of shares owned by the directors on the board. Jensen and Meckling (1976) argue that share ownership can align the incentives of outsiders with shareholders. The average board shareholding is $29.8 \%$. Duality is a dummy variable coded one when the CEO is also the chairperson of the board. Concentrating power in one person's hands runs the risk that any abuse of power will be harder to prevent (Jensen, 1993). About $28 \%$ of firms have a joint CEO-chairman. Independent Director is the number of independent directors on the board ${ }^{16}$. Independent directors are more likely to deter the top executives from pursuing personal objectives and, instead, force management to focus on firm value (Chen, Firth, Gao and Rui, 2006). ${ }^{17}$

\subsubsection{Other Control Variables}

We include control variables to capture possible confounding effects. Other Controls is a vector of control variables, which comprise of Firm Size, Firm Age and Business Group. Firm Size is measured as the log of total assets and Firm Age is the log of the number of years since the enterprise was established. Business Group is a dummy variable, which is equal to 1 if a firm belongs to a business group. We expect positive coefficients on Firm Size and Firm Age as larger and older firms are better known to bankers. A negative sign is, however, expected on Business Group because firms belonging to a business group may have access to

\footnotetext{
${ }^{16} \mathrm{We}$ do not use the board independence ratio here because some firms do not have a board in our sample.

${ }^{17}$ In addition to managerial compensation contracts and board characteristics, concentration of ownership may also be a concern to banks because firms with a more concentrated ownership structure are plagued less by managerial problems (Shleifer and Vishny 1997). Unfortunately, the survey does not include any information on the shareholdings of the various large shareholders. We therefore have to leave this important issue for future research.
} 
finance through the internal capital market and thus have a lower demand for external bank loans ${ }^{18}$ (Gertner, Scharfstein, and Stein, 1994; Khanna and Tice, 2001). Additional control variables are GDP per Capita (of the city where the firm is located) and City Population. Industry dummies are also included in the regressions.

We also check the correlations among the firm specific variables and find that multicollinearity is not a serious problem. Most of the correlation coefficients are below 0.3 , which gives us confidence to include these variables in the models simultaneously. For brevity, the correlation matrix is not reported but it is available from the authors upon request.

\section{Empirical Results}

\subsection{Base Results}

Tables 4 and 5 report our baseline models. In order to get some sense of the magnitude of the effects, the coefficient estimates are transformed to represent the marginal effects evaluated at the means of the independent variables from the Probit and Tobit regressions. The marginal effect of a dummy variable is calculated as the discrete change in the expected value of the dependent variable as the dummy variable changes from 0 to 1 . Lagged Return on Sales (ROS) is significantly and positively related to both Access to Banking Finance and Size of Banking Finance. This result holds irrespective of various period lags and alternative proxies for a firm's previous performance ${ }^{19}$. A one standard deviation increase in a firm's one year lag return on sales is associated with an increase of about 5 percentage points in the probability of obtaining bank credit, depending on the specification of the model (Table 4). A one standard deviation increase in a firm's return on sales performance will increase the scaled loan size by 1.09 percentage points (Table 5). Given the fact that the mean of scaled loan size is 4.66 percentage points, the effect is not trivial. Our results are consistent with those obtained by Cull and $\mathrm{Xu}$ (2005), which suggest that banks tend to allocate loans to private firms with better operating performance. The

\footnotetext{
${ }^{18}$ The survey has no additional information on the characteristics of the business group. As a result, we are not able to examine the issue of how the characteristics of the business group affect credit allocation and so we have to leave this important question for future research.

${ }^{19}$ We use one-year lag performance indicators, two-year lag performance indicators and the average of the two. Moreover, we employ return on sales and return on assets as two alternative proxies for firm performance. The positive effect of previous performance on firms' access to finance and credit size remain significant. Note, the firms are not listed and so we are unable to use stock market measures of performance.
} 
results indicate that banks use commercial judgment in providing loans to private firms ${ }^{20}$. In the absence of reliable repayment history information and a reliable credit scoring system, banks appear to rely on a company's financial reports when conducting a credit screening process for loan applications from private firms.

\section{[Tables 4 and 5 Here]}

Columns 2 and 4 of Tables 4 and 5 report the effects of political connections. State Minority Ownership is related positively to both Access to Banking Finance and Size of Banking Finance although it is only significant for the models of Access to Banking Finance. This suggests that state minority ownership is instrumental for getting access to bank loans. The coefficients for the other two political connections variables (CEO Government Officials and Business Connections) are not statistically significant (and so we do not include them in column 4). Consistent with prior research studies, which document that political connections are important for listed firms (e.g., Fisman, 2001; Faccio et al., 2005), our results suggest that political connections (in the form of the state's minority ownership) play a role in private firms when it comes to borrowing from state owned banks. As we have discussed previously, lending to firms that have state minority ownership may not be necessarily driven by purely political considerations and biases. Banks may lend to these firms because of informational reasons as well as the possible bailouts or other supports from the government. Given the data we have, it is not possible to distinguish between these reasons for the positive sign on minority state ownership.

Columns 3 and 4 of Tables 4 and 5 show the effects of corporate governance. The CEO experience and incentive variables are positively related to both Access to Banking Finance and Size of Banking Finance, suggesting that banks tend to allocate bank loans to firms with more experienced and incentive-driven CEOs. A one year increase in CEO experience is associated with a $0.7 \%$ increase in the probability of getting credit from banks and a $0.102 \%$ to $0.105 \%$ increase in the loan size scaled by total assets. The probability of getting bank credit for private firms that have adopted the Annual Salary System dominates

\footnotetext{
${ }^{20}$ Previous studies (e.g., Cull and $\mathrm{Xu}, 2003$ ) find no relationship between firm performance and access to finance in a sample of SOEs. However, when private firms are competing with each other for bank loans, it is not too surprising to observe that firm performance plays an important role in bank loan decisions.
} 
those without such incentive payment schemes by $7.3 \%$ to $7.5 \%$ depending on the model specification. Firms with such incentive arrangements also enjoy larger scaled bank loans in the order of $1.84 \%$ to $1.88 \%$. Similar results also hold for CEO ownership variables. For example, if the CEO owns shares in the firm the Access to Banking Finance increases by 5\% and the Size of Banking Finance increases by about $0.692 \%$. The use of managerial experience and incentive compatibility as signals for borrowers' quality by Chinese banks is somewhat comparable with the use of information from credit bureaus and proprietary information from financial institutions for small business credit scoring in the U.S. and other developed economies. This information relies mostly on information on the owner rather than firm itself and can significantly reduce the loan processing cost (Kallberg and Udell, 2003).

Turning to the board characteristic variables, CEO duality is related negatively to Access to Banking Finance and Size of Banking Finance at the 5\% level, suggesting banks are more likely to make larger loans to firms when two separate persons occupy the positions of CEO and board chairperson. Board Ownership, on the other hand, is related positively to Access to Banking Finance and Size of Banking Finance. This provides support for the positive role of directors' share ownership in signaling a firm's quality to the banks. Independent Director is related positively to Size of Banking Finance at the 1\% level, which suggests that banks tend to allocate larger loans to firms with more independent directors. Overall, our evidence is consistent with banks analyzing the board structures of prospective borrowers when deciding whether to lend to private firms and the amount to lend. Therefore, good governance mechanisms serve as an effective signal for borrowers' quality in the eyes of banks, and thereby facilitate access to formal finance.

\subsection{Further Tests}

Theoretically, in a world with fixed transaction costs and information asymmetries, small firms with a demand for loans face higher transaction costs, and face higher risk premiums since they are typically less transparent and have less collateral to offer. In other words, small firms are more informationally opaque and thus riskier than large firms in the eyes of the banks. As a result, small and medium enterprises tend to have a lower capacity to signal their quality because of their less reliable financial information and lower market 
power. The results in Tables 4 and 5 attest to the size effect. To take a closer look at whether the experimental variables have different impacts across large and small firms, we divide our sample into two groups according their asset size. A firm is classified as a large (small) firm if its asset size is above (below) the sample median. In unreported summary statistics of our sample, $33 \%$ of the large firms get access to bank finance while only $10.8 \%$ of the small firms get access to bank finance. The average scaled loan size for large firms is $7.06 \%$ and it is only $2.23 \%$ for small firms.

Table 6 reports the results on the determinants of loan access for large and small firms separately. For large firms, financial performance is related positively and significantly to Access to Banking Finance and Size of Banking Finance (Columns 1, 2, 5 and 6 in Table 6). However, there is no significant relation for small firms (Columns 3, 4, 7 and 8 in Table 6). The results suggest that accounting performance is a positive signal for large firms but not for small firms, which may be partly attributed to the unreliable nature of financial reports of small firms.

For large firms only, State Minority Ownership is found to exert a positive effect on Access to Banking Finance and Size of Banking Finance. For large firms, CEO experience is related positively and significantly to Access to Banking Finance, and ownership of stock by the CEO is significantly and positively related to Access to Banking Finance and Size of Banking Finance. Except for Annual Salary System and Board Ownership in the Access to Banking Finance regressions, political connections and corporate governance do not serve as useful signals for small firms. Overall, the results corroborate our contention that small firms lack the ability to signal their quality to banks.

\section{[Table 6]}

Firms in our sample operate in different industries so they are subject to different industry conditions such as market competition, asset structure and level of information asymmetry (Aggarwal and Zhao, 2007). Varying industrial conditions provide firms with differing opportunities to earn profits and pose different credit risks on the banks. As a control for this, we include industry dummies to remove the possible confounding industry effects. To gain further insights, we also divide our sample firms into services and 
manufacturing firms to examine whether banks use different criteria in evaluating borrowers from different industries.

Table 7 reports the results on the determinants of loan access and size of bank finance for service and manufacturing firms, separately. Two important differences between services and manufacturing industries stand out. First, financial performance is related positively and significantly to Access to Banking Finance and Size of Banking Finance for manufacturing firms only (Columns 3, 4, 7 and 8 in Table 8) and they are not significant for the service firms (Columns 1, 2, 5 and 6 in Table 8). Firms in the service industry face lower barriers to entry and are therefore subject to more threats from potential entrants. Consequently, the historical profitability of a service industry firm is a less informative indicator of current or future performance. Banks will therefore place less weight on $R O S$ when deciding whether to lend to service industry firms. Second, State Minority Ownership has a positive and significant effect on Access to Banking Finance and Size of Banking Finance for service firms but not for manufacturing firms. This may be due to the fact that services firms tend to have fewer tangible assets to serve as collaterals than manufacturing firms. The banks therefore put a greater emphasis on state ownership, which can serve as a kind of implicit collateral. Board characteristics appear to be more important in lending decisions for manufacturing firms. In sum, our results suggest that the banks in China take different industry conditions into account when they extend loans to the private sector.

[Table 7]

In addition to different industry conditions, our sample firms also operate under various institutional environments because different regions in China are moving towards a market-based economy at different paces (Fan, Wong and Zhang 2007). In order to ensure that our results are not caused by institutional heterogeneity, we control for different market development conditions by using the NERI (National Economic Research Institute of China) marketization indexes (Fan and Wong, 2006); these indexes have been employed also by Fan et al. (2007) and Chen et at. (2006) $)^{21}$. Tables 8 and 9 show that our results are robust ${ }^{22}$ after

\footnotetext{
${ }^{21}$ Specifically, the NERI market development index (known as the marketization index) is based on the following indicators of a well-functioning market system: (i) The relationship between provincial government and markets, including the size of the provincial government; the financial burden of firms besides normal taxes;
} 
controlling for the different involvement of the government in the economy (Government and Market) as well as different degrees of private sector development (Development of Non-state Sector), product market development (Development of Product Market), banking liberalization (Banking Sector Marketization) and legal infrastructure development (Legal Environment). Furthermore, Banking Sector Marketization is found to exert a positive and significant effect on access to bank loans and size of the loan. In contrast, the other market development indexes are not significant.

\section{[Tables 8 and 9]}

To gain further insights into the impact of the development of the banking sector on our results, we split the sample into two groups, firms located in areas with a more developed banking sector and those located in areas with a less developed banking sector. Since the banking marketization index ranges from 0 to 10 , the sample is divided into two sub-samples using the natural cutoff point 5 and we examine how the degree of banking marketization affects the determinants of loan access and size of loan to the private firms. The results are reported in Table 10. Banking marketization changes the relative importance of financial performance and state minority ownership as determinants of bank loans. While financial performance is related positively and significantly to both Access to Banking Finance and Size of Banking Finance for firms in regions with a more marketized banking sector, a positive but non-significant relation is found for firms in regions with a less marketized banking sector. On the other hand, state minority ownership is instrumental in obtaining bank loans for firms in areas with a less developed banking sector. It, however, plays no role in lending decisions for firms in regions with a more developed banking sector. Our results

and the level of government intervention and efficiency. (ii) Development of non-state sectors, including the ratio of private sector employees and total labor force and the ratio of private sector and total industrial outputs. (iii) Development of product markets, including the extent of price deregulation and the size of inter-regional trade barriers. (iv) Development of factor markets, including competition and liberalization in the banking sector; improvement in investment policies and environment (FDI as a percentage of total investment); and labor mobility. (v) Development of a legal framework for property protection and contract enforcement, including the development of market institutions (the number of law firms, accounting offices and independent auditing offices adjusted for differences in population); market order (the number of cases of trademark violations); property rights protection (the number of patent applications and actual registrations); and consumer protection (the number of legal cases involving consumer complaints). For each of the above indicators, Fan and Wang (2006) assign a value between 0 and 10, with the higher values indicating a higher degree of market development and economic freedom.

${ }^{22}$ For the sake of brevity, we omit CEO government official and Business Connection as they are not significant. 
suggest that banks in China are becoming more commercialized as China continues to reform its banking sector. While the importance of political connections will decline over time as the banking sector becomes more developed, financial performance will become a more important determinant of credit allocation to the private sector, and thus more bank loans will be allocated to firms with greater profitability.

[Table 10]

\section{Conclusion}

A major contributor to China's growth has been the spectacular expansion of the private sector. This expansion is even more remarkable given the lack of a conventional financial infrastructure in China (Allen et al., 2005). In this study, we seek to determine whether state banks do, in fact, lend to private non-listed firms and what criteria they use in evaluating loan applications. The data come from a survey of private businesses and so our models are constrained by the information collected.

We find that obtaining a loan is quite difficult, but commercial criteria appear to be used in banks' decision making. In particular, a firm's profitability is used as a criterion in granting loans and in determining the amount borrowed. This finding is much more pronounced for large firms, firms in the manufacturing industry, and firms in regions with a more developed banking sector. Despite these promising developments, political connections via state minority ownership still plays a significant role in getting access for bank loans for large firms, firms in the service industry and firms in regions with a less developed banking sector. China's banking sector is in a transitional stage where credit allocation is subject to the influences of both economic and political factors. Given the continuing bank reforms in China, we expect that bank loans to the private sector will increasingly be allocated based on commercial considerations in the coming years.

We find that in the absence of credit bureaus and the exchange of loan information across the banking sector, banks rely on corporate governance as signals for borrowers' quality. Our study therefore makes a useful complement to the literature that documents the positive roles of corporate governance in reducing the costs of debt financing. We show that, in a lending environment with severe asymmetric information, good corporate governance 
can serve as organization collateral to facilitate access to bank loans.

We also find that small private firms in China have a lower capacity to signal their quality to the banks. The lack of effective signals for small firms indicates that outside guarantee services could play a useful role in facilitating private firms' access to bank loans. The establishment of a nation-wide credit scoring system and an inter-bank information sharing database on loan repayment history would substantially reduce transaction costs and reduce information asymmetry in the lending process. However, China's credit guarantee companies currently serve only about 1 percent of the country's SMEs and so there is an urgent need for China to develop additional standard credit guarantee services.

The Chinese government continues to recognize the importance of the banking sector and has promulgated further rules and regulations that will help create a more level playing field between private, public and mixed private-public firms. The rules also require banks to use commercial criteria in making loans and to make them accountable for making bad decisions. As examples, in July 2004 and May 2005, the government promulgated Guidelines on Commercial Banks' Due Diligence Performance in Credit Business and Guidelines on Banks' Lending to Small Enterprises. These require each bank to clearly define the responsibilities and due diligence assessment criteria for every function involved in the lending process and create a fair credit market and competitive lending culture to firms with differing ownership structures. The recent listing of state banks on domestic and foreign stock markets exerts external market pressures on banks and should reinforce the use of commercial criteria in lending decisions and reduce any discrimination against small private firms. In light of this, we expect that the financing of small private firms will, in the fullness of time, come to resemble the situation in the U.S. and other developed nations. 


\section{References}

Aggarwal, R,. Zhao, X., 2007. The leverage-value relationship puzzle: An industry effects resolution. Journal of Economics and Business 59, 286-297.

Anderson, R.C., Mansi, S.A., Reeb, D.M., 2004. Board characteristics, accounting report integrity, and the cost of debt. Journal of Accounting and Economics 37, 315-342.

Allen, F. Qian M., Qian, J., 2005. Law, finance, and economic growth in China. Journal of Financial Economics 77, 57-116.

Ashbaugh-Skaife, H., Collins, D., LaFond, R., 2006. The effects of corporate governance on firms' credit ratings. Journal of Accounting and Economics 42, 203-243.

Bhojraj, S., Sengupta, P., 2003. Effect of corporate governance on bond ratings and yields: The role of institutional investors and outside directors. Journal of Business 76, 455-475.

Barth, J., Lin, C., Lin, P., Song, M., 2008. Corruption in bank lending to firms: Cross-country micro evidence on the beneficial role of competition and information sharing. Journal of Financial Economics, forthcoming.

Beck, T., Demirguc-Kunt, A., 2006. Small and medium-size enterprises: Access to finance as a growth constraint. Journal of Banking \& Finance 30, 2931-2943.

Berger, A., Udell, G., 2006. A more complete conceptual framework for SME finance. Journal of Banking and Finance 30, 2945-2966.

Berger, A., Hasan, I., Zhou, M., 2009. Bank ownership and efficiency in China: What will happen in the world's largest nation? Journal of Banking \& Finance 33, 113-130.

Biggs, T., Shah, M., 2006. African SMEs, networks, and manufacturing performance. Journal of Banking and Finance 30, 3043-3066.

Brandt, L., Li, H.B., 2003. Bank discrimination in transition economies: Ideology, information or incentives? Journal of Comparative Economics 31, 387-413.

Chava, S., Livdan, D., Purnanandam, A., 2008. Do shareholder rights affect the cost of bank loans? Review of Financial Studies, forthcoming.

Chen, G.M., Firth, M., Yu, X., Xu, L.P., 2008. Control transfers, privatization, and corporate performance: Efficiency gains in China's listed companies. Journal of Financial and Quantitative Analysis 43, 161-190.

Chen, G.M., Firth, M., Gao, D., Rui, O.M., 2006. Ownership structure, corporate governance, and fraud: Evidence from China. Journal of Corporate Finance 12, 424-448.

Cull, R., Xu, L.X., 2003. Who gets credit? The behavior of bureaucrats and state banks in allocating credit to Chinese state-owned enterprises. Journal of Development Economics 71, 533-559.

Cull, R., Xu, L.X., 2005. Institutions, ownership, and finance: The determinants of profit reinvestment among Chinese firms. Journal of Financial Economics 77, 117-146.

Demirgüç-Kunt, A., Maksimovic, V., 1998. Law, finance, and firm growth. Journal of Finance 53, 2107-2137. 
Dinc, S., 2005. Politicians and banks: Political influences on government-owned banks in emerging markets. Journal of Financial Economics 77, 453-479.

Dobson, W., Kashyap, A., 2006. The contradiction in China's gradualist banking reforms, Brookings Papers on Economic Activity 2, 103-145.

Faccio, M., Masulis, R., McConnell, J., 2005. Political connections and corporate bailouts. Journal of Finance 61, 2597-2635.

Fan, J., Wong, T.J., Zhang, T.Y., 2007. Politically connected CEOs, corporate governance, and postIPO performance of China's newly partially privatized firms. Journal of Financial Economics 84, 330357.

Ferri, G., 2009. Are New Tigers supplanting Old Mammoths in China's banking system? Evidence from a sample of city commercial banks. Journal of Banking \& Finance 33, 131-140.

Firth, M., Fung, M.Y., Rui, O.M., 2006. Corporate performance and CEO compensation in China. Journal of Corporate Finance 12, 693-714.

Firth, M., Fung, M.Y., Rui, O.M., 2007. Ownership, two-tier board structure, and the informativeness of earnings-evidence from China. Journal of Accounting and Public Policy 26, 463-496.

Fisman, R., 2001. Estimating the value of political connections. American Economic Review 91, 1095-1102.

Fu, X., Heffernan, S., 2009. The effects of reform on China's bank structure and performance. Journal of Banking \& Finance 33, 39-52.

Ge, Y., Qiu, J.P., 2007. Financial development, bank discrimination and trade credit. Journal of Banking and Finance 31, 513-530.

Gertner, R., Scharfstein, D., Stein, J., 1994. Internal versus external capital markets. Quarterly Journal of Economics 109, 1211-1230.

Graham, J.R., Li, S., Qiu, J.P., 2008. Corporate misreporting and bank loan contracting. Journal of Financial Economics 89, 44-61.

Jensen, M., 1993. The modern industrial revolution, exit and the failure of internal control systems. Journal of Finance 48, 831-880.

Jensen, M., Meckling, W., 1976. Theory of the firm: managerial behavior, agency costs and ownership structure. Journal of Financial Economics 3, 305-360.

Jia, C., 2009. The effect of ownership on the prudential behavior of banks - The case of China. Journal of Banking \& Finance 33, 77-87.

Kallberg, J., Udell, G., 2003. The value of private sector credit information: The U.S. case. Journal of Banking and Finance 27, 449-469.

Khanna, N., Tice, S., 2001. The bright side of internal capital markets. Journal of Finance 56, 14891528.

Khwaja, A.I., Mian, A., 2005. Do lenders favor politically connected firms? Rent provision in an emerging financial market. Quarterly Journal of Economics 120 (4), 1371 - 1411 
King, R., Levine, R., 1993. Finance and growth: Schumpeter might be right. Quarterly Journal of Economics 108, $717-738$.

Kroszner, R., Laeven, L., Klingebiel, D., 2007. Banking crisis, financial dependence and growth. Journal of Financial Economics 84, 187-228.

La Porta, R., Lopez-de-Silanes, F., Shleifer, A., Vishny, R., 1997. Legal determinants of external finance. Journal of Finance 52, 1131 - 1150.

La Porta, R., Lopez-de-Silanes, F., Shleifer, A., Vishny, R., 1999. The quality of government. Journal of Law, Economics, and Organization 15, 222 - 279.

La Porta, R., Lopez-de-Silanes, F., Shleifer, A., Vishny, R., 2000. Investor protection and corporate governance. Journal of Financial Economics 58, 141 - 186.

La Porta, R., Lopez-de-Silanes, F., Shleifer, A., Vishny, R., 2002a. Investor protection and corporate valuation. Journal of Finance 57, $1147-1170$.

La Porta, R., Lopez-de-Silanes, F., Shleifer, A., 2002b. Government ownership of banks. Journal of Finance 57, 265-302.

Li, H.B., Meng, L.S., Wang, Q., Zhou, L.A., 2007. Political connections, financing and firm performance: Evidence from Chinese private entrepreneurs. Journal of Development Economics, forthcoming.

Lin, C., Lin, P., Song, M., 2008. Property rights protection and corporate R\&D: Evidence from China. working paper, University of Hong Kong.

Lin, X. and Zhang, Y., 2009. Bank ownership reform and bank performance in China. Journal of Banking \& Finance 33, 20-29.

Lardy, N., 1998. China's Unfinished Economic Revolution. Brookings Institution Press, Washington, DC.

Miller, M., 2003. Credit reporting systems around the Globe: The state of the art in public credit registries and private credit reporting firms. In Credit Reporting Systems and International Economy, Margaret J. Miller, ed., Cambridge, MA: MIT Press.

Mitton, T., 2002. A cross-firm analysis of the impact of corporate governance on the East Asian financial crisis. Journal of Financial Economics 64, 215-241.

Pagano, M., Tullio J., 1993. Information sharing in credit markets. Journal of Finance 48, 1693-1718.

Park, A., Shen, M.G., 2003. Joint liability lending and the rise and fall of China's township and village enterprises. Journal of Development Economics 71, 497- 531.

Petersen, M., Rajan, R., 1994. The benefits of lending relationships: Evidence from small business data. Journal of Finance 47, 3-37.

Podpiera, R., 2006. Progress in China's banking sector reform: Has bank behavior changed? IMF Working Paper.

Rajan, R., Zingales, L., 1998. Financial dependence and growth. American Economic Review 88, 559-596. 
Sapienza, P., 2004. The effects of government ownership on bank lending. Journal of Financial Economics 72, 357-384.

Shleifer A., Vishny, R. W., 1997. A Survey of Corporate Governance. Journal of Finance 52, $737-$ 783.

Stein, J., 2002. Information production and capital allocation: Decentralized versus hierarchical firms. Journal of Finance 57, 1891-1921.

Tsai, S., 2007. Capitalism without democracy: The private sector in contemporary China. Ithaca, NY: Cornell University Press.

Tung, C.Y., 2002. Current problems and reforms of the Chinese financial system. USA-China Business Review 2 (1) Serial No. 2.

Wong R.Y.C., Wong S.M.L., 2001. Competition in China's domestic banking industry, Cato Journal 21, 19-41.

Wu, L., and Yue, H., 2009. Corporate tax, capital structure, and the accessibility of bank loans: Evidence from China. Journal of Banking \& Finance 33, 30-38

Uzun, H., Szewczyk, S., Varma, R., 2004. Board composition and corporate fraud. Financial Analysts Journal 60 (3), 33-43. 
Table 1: Characteristics of the state owned and non-state owned economy (1995-2005)

\begin{tabular}{|c|c|c|c|c|c|}
\hline $\begin{array}{l}\text { Number of } \\
\text { Employees } \\
\text { in Nonstate } \\
\text { enterprises } \\
\text { (million) }\end{array}$ & $\begin{array}{l}\text { Employment in } \\
\text { Nonstate } \\
\text { enterprises to } \\
\text { Total urban } \\
\text { Employment \% }\end{array}$ & $\begin{array}{l}\text { Industrial } \\
\text { Production } \\
\text { of SOEs } \\
\text { (billion) }^{\text {a }}\end{array}$ & $\begin{array}{l}\text { Industrial } \\
\text { Production of } \\
\text { Nonstate } \\
\text { enterprises to } \\
\text { Total } \\
\text { Industrial } \\
\text { Production \% }\end{array}$ & $\begin{array}{l}\text { Tax } \\
\text { Revenue } \\
\text { from } \\
\text { SOEs } \\
\text { (billion) }\end{array}$ & $\begin{array}{l}\text { Tax Revenue } \\
\text { from Nonstate } \\
\text { enterprises to } \\
\text { Total Tax } \\
\text { Revenue \% }\end{array}$ \\
\hline
\end{tabular}

\begin{tabular}{lllllll}
\hline 1985 & 48.71 & 29.81 & 630.2 & 35.14 & 32.89 & 27.46 \\
1986 & 56.55 & 29.8 & 697.1 & 37.73 & 37.44 & 29.3 \\
1987 & 65.09 & 29.96 & 825 & 40.27 & 41.85 & 30.4 \\
1988 & 75.93 & 30.03 & $1,035.10$ & 43.2 & 49.76 & 31.5 \\
1989 & 79.23 & 30.03 & $1,234.30$ & 43.94 & 60.3 & 32.05 \\
1990 & 85.99 & 29.76 & $1,306.40$ & 45.39 & 61.79 & 31.41 \\
1991 & 83.21 & 38.94 & $1,495.50$ & 43.83 & 67.19 & 31.71 \\
1992 & 102.46 & 36.84 & $1,782.40$ & 48.48 & 76.9 & 33.03 \\
1993 & 123.39 & 37.92 & $2,272.50$ & 53.05 & 144.68 & 36.44 \\
1994 & 188.18 & 39.1 & $2,620.10$ & 62.66 & 174.77 & 36.96 \\
1995 & 218.89 & 41.02 & $3,122.00$ & 66.03 & 222.04 & 40.26 \\
1996 & 282.36 & 43.26 & $2,836.10$ & 71.52 & 245.17 & 45.31 \\
1997 & 322.32 & 45.35 & $2,902.80$ & 74.48 & 299.64 & 43.67 \\
1998 & 91.93 & 58.1 & $3,362.10$ & 50.37 & 397.8 & 45.95 \\
1999 & 89.5 & 61.75 & $3,557.12$ & 51.08 & 489.12 & 50.49 \\
2000 & 90.12 & 65 & $4,055.44$ & 52.66 & 693.6 & 58.5 \\
2001 & 95.56 & 68.09 & $4,240.85$ & 55.57 & 954.2 & 64 \\
2002 & 104.02 & 71.09 & $4,517.90$ & 59.22 & 1127.39 & 67.78 \\
2003 & 114.4 & 73.18 & $5,340.79$ & 62.46 & 1409.86 & 70.53 \\
2004 & 125.66 & 74.66 & $7,022.90$ & 65.19 & 1833.89 & 72.8 \\
2005 & 130.07 & 76.26 & 8375.00 & 66.72 & &
\end{tabular}

Note ${ }^{\mathrm{a}}$ :

For industrial production, there is a change in classification of SOE in 1998. SOEs include only wholly state-owned enterprises for years prior to 1998. Since 1998, SOEs include wholly state-owned and statecontrolled enterprises. "Nonstate enterprises" include foreign investment firms and Sino-foreign joint ventures. Source: China Statistics Yearbook, various years. Tax Yearbook of China, various years. 
Table 2: Definitions of variables

\begin{tabular}{|c|c|}
\hline Variables & Definition \\
\hline \multicolumn{2}{|l|}{ Banking finance } \\
\hline Access to banking finance & $\begin{array}{l}\text { a dummy variable that equals one if a firm's answer to the } \\
\text { question "Do you have a loan from a bank or financial } \\
\text { institution?" is "Yes", zero otherwise }\end{array}$ \\
\hline Size of banking finance & $\begin{array}{l}\text { the amount of the line of credit reported by the managers scaled by } \\
\text { the firm's total assets }\end{array}$ \\
\hline \multicolumn{2}{|l|}{ Firm performance } \\
\hline Lagged ROS & one year lagged operating profit divided by total sales \\
\hline Lagged ROA & one year lagged operating profit divided by total assets \\
\hline \multicolumn{2}{|c|}{$\begin{array}{l}\text { Managerial characteristics and } \\
\text { incentives }\end{array}$} \\
\hline CEO experience & $\begin{array}{l}\text { the manager's response to the question "How many years has the } \\
\text { general manager held this position in the firm and previous firms?" } \\
\text { a dummy variable that equals one if the manager's response to the }\end{array}$ \\
\hline CEO ownership & $\begin{array}{l}\text { question "Does the general manager own company stocks?" is "Yes", } \\
\text { zero otherwise }\end{array}$ \\
\hline Annual salary system & $\begin{array}{l}\text { a dummy variable that equals one if the manager's answer to the } \\
\text { question "Is the general manager's wage paid annually [i.e., Nian Xin } \\
\text { Zhi]?", zero otherwise }\end{array}$ \\
\hline \multicolumn{2}{|l|}{ Political connection } \\
\hline State Minority Shareholder & $\begin{array}{l}\text { A dummy variable that equals one if the state is a minority } \\
\text { shareholder of the private firm }\end{array}$ \\
\hline CEO government official & $\begin{array}{l}\text { a dummy variable that equals one if the manager's answer to the } \\
\text { question "Before becoming general manager in this firm, what was } \\
\text { his/her position?" is "government official", zero otherwise }\end{array}$ \\
\hline Business Connection & $\begin{array}{l}\text { a dummy variable that equals one if the share of the firm's sales to } \\
\text { the government is larger than zero, zero otherwise }\end{array}$ \\
\hline \multicolumn{2}{|l|}{ Corporate governance } \\
\hline Board Size & number of directors on a firm's board \\
\hline Duality & $\begin{array}{l}\text { a dummy variable that equals one if the general manager possesses } \\
\text { dual positions both as a general manager and board chair, zero } \\
\text { otherwise }\end{array}$ \\
\hline Independent Director & Number of independent directors on a firm's board \\
\hline Board Ownership & Proportion of a firm's shares owned by board members \\
\hline \multicolumn{2}{|l|}{ Other controls } \\
\hline Group & $\begin{array}{l}\text { A dummy variable that equals one if the firm belongs to a business } \\
\text { group, zero otherwise }\end{array}$ \\
\hline Firm Age & logarithm form of years since the firm was established \\
\hline Firm Size & logarithm form of a firm's total assets (in 1,000 yuan) \\
\hline GDP per Capita & $\begin{array}{l}\text { logarithm form of gross domestic product per capita of the city where } \\
\text { the firm is located }\end{array}$ \\
\hline City Population & $\begin{array}{l}\text { logarithm form of population of the city where the firm is located } \\
\text { Five categories of market development (marketization) indexes: }\end{array}$ \\
\hline $\begin{array}{l}\text { Market Development } \\
\text { (Marketization) indexes }\end{array}$ & $\begin{array}{l}\text { Government and Market; Development of Non-State Sector; } \\
\text { Development of Product Market; Banking Sector Marketization; } \\
\text { Legal Environment }\end{array}$ \\
\hline
\end{tabular}


Table 3: Summary statistics of main variables

\begin{tabular}{|c|c|c|c|c|}
\hline Variables & Number of obs. & Mean & Median & Standard deviation \\
\hline Access to banking finance & 1814 & 0.222 & 0 & 0.415 \\
\hline $\begin{array}{c}\text { Size of banking finance } \\
\text { [\% of total asset] }\end{array}$ & 1775 & 4.66 & 0 & 12.44 \\
\hline \multicolumn{5}{|l|}{ Firm performance } \\
\hline Lagged ROS & 1841 & 0.106 & 0.102 & 0.430 \\
\hline \multicolumn{5}{|l|}{ Political Connection } \\
\hline State Minority Shareholder & 1869 & 0.030 & 0 & 0.172 \\
\hline CEO government official & 1856 & 0.053 & 0 & 0.225 \\
\hline Business Connection & 1869 & 0.220 & 0 & 0.415 \\
\hline \multicolumn{5}{|l|}{$\begin{array}{c}\text { Managerial characteristics and } \\
\text { incentives }\end{array}$} \\
\hline CEO experience & 1868 & 6.753 & 6 & 4.696 \\
\hline CEO ownership & 1869 & 0.357 & 0 & 0.479 \\
\hline Annual salary system & 1869 & 0.204 & 0 & 0.403 \\
\hline \multicolumn{5}{|l|}{ Board Characteristics } \\
\hline Board Ownership & 1840 & 0.298 & 0 & 0.415 \\
\hline Duality & 1860 & 0.283 & 0 & 0.451 \\
\hline Independent Director & 1856 & 0.484 & 0 & 1.253 \\
\hline \multicolumn{5}{|l|}{ Other controls } \\
\hline Firm Age & 1869 & 2.197 & 2.260 & 0.707 \\
\hline Firm Size & 1834 & 9.427 & 9.326 & 2.239 \\
\hline GDP per Capita & 1869 & 10.00 & 10.00 & 0.374 \\
\hline City population & 1869 & 5.394 & 5.532 & 0.617 \\
\hline \multicolumn{5}{|l|}{ Marketization Indexes } \\
\hline Government and Market & 1869 & 7.00 & 6.90 & 0.935 \\
\hline Development of Non-state Sector & 1869 & 5.81 & 5.24 & 2.962 \\
\hline Development of Product Market & 1869 & 7.47 & 7.43 & 1.605 \\
\hline Banking Sector Marketization & 1869 & 5.98 & 5.87 & 2.302 \\
\hline Legal Environment & 1869 & 4.22 & 3.29 & 2.164 \\
\hline
\end{tabular}


Table 4: Probit regressions on the determinants of access to bank finance Variables

Access to Bank Finance

\begin{tabular}{|c|c|c|c|c|}
\hline & [1] & [2] & [3] & [4] \\
\hline \multicolumn{5}{|l|}{ Performance } \\
\hline \multirow[t]{2}{*}{ Lagged ROS } & 0.116 & 0.118 & 0.110 & 0.111 \\
\hline & {$[0.006]^{* * *}$} & {$[0.005]^{* * *}$} & {$[0.011]^{* *}$} & {$[0.011]^{* *}$} \\
\hline \multicolumn{5}{|l|}{ Political Connection } \\
\hline \multirow{2}{*}{ State minority ownership } & & 0.128 & & 0.114 \\
\hline & & {$[0.023]^{* *}$} & & {$[0.047]^{* *}$} \\
\hline \multirow[t]{2}{*}{ CEO government official } & & -0.039 & & \\
\hline & & {$[0.416]$} & & \\
\hline \multirow[t]{2}{*}{ Business Connection } & & 0.024 & & \\
\hline & & {$[0.312]$} & & \\
\hline \multicolumn{5}{|l|}{ Managerial Incentives } \\
\hline \multirow[t]{2}{*}{ CEO experience } & & & 0.007 & 0.007 \\
\hline & & & {$[0.002]^{* * *}$} & {$[0.002]^{* * *}$} \\
\hline \multirow[t]{2}{*}{ CEO ownership } & & & 0.050 & 0.049 \\
\hline & & & {$[0.042]^{* *}$} & {$[0.044]^{* *}$} \\
\hline \multirow[t]{2}{*}{ Annual salary system } & & & 0.073 & 0.075 \\
\hline & & & {$[0.003]^{* * *}$} & {$[0.003]^{* * *}$} \\
\hline \multicolumn{5}{|l|}{ Board Characteristics } \\
\hline \multirow[t]{2}{*}{ Duality } & & & -0.056 & -0.054 \\
\hline & & & {$[0.017]^{* *}$} & {$[0.021]^{* *}$} \\
\hline \multirow[t]{2}{*}{ Independent Director } & & & 0.010 & 0.009 \\
\hline & & & {$[0.166]$} & {$[0.174]$} \\
\hline \multirow[t]{2}{*}{ Board Ownership } & & & 0.059 & 0.056 \\
\hline & & & {$[0.039]^{* *}$} & {$[0.051]^{*}$} \\
\hline \multicolumn{5}{|l|}{ Other controls } \\
\hline \multirow[t]{2}{*}{ Business Group } & -0.054 & -0.054 & -0.050 & -0.051 \\
\hline & {$[0.014]^{* *}$} & {$[0.014]^{* *}$} & {$[0.029]^{* *}$} & {$[0.026]^{* *}$} \\
\hline \multirow[t]{2}{*}{ Firm Age } & -0.010 & -0.013 & -0.012 & -0.014 \\
\hline & {$[0.452]$} & {$[0.367]$} & {$[0.400]$} & {$[0.336]$} \\
\hline \multirow[t]{2}{*}{ Firm Size } & 0.068 & 0.065 & 0.067 & 0.065 \\
\hline & {$[0.000]^{* * *}$} & {$[0.000]^{* * *}$} & {$[0.000]^{* * *}$} & {$[0.000]^{* * *}$} \\
\hline \multirow[t]{2}{*}{ GDP per Capita } & -0.020 & -0.015 & -0.029 & -0.027 \\
\hline & {$[0.502]$} & {$[0.615]$} & [0.337] & {$[0.366]$} \\
\hline \multirow[t]{2}{*}{ City Population } & -0.025 & -0.023 & -0.034 & -0.033 \\
\hline & {$[0.153]^{*}$} & {$[0.200]$} & {$[0.063]^{*}$} & {$[0.072]^{*}$} \\
\hline Industry dummies & Yes & Yes & Yes & Yes \\
\hline Observations & 1723 & 1716 & 1683 & 1683 \\
\hline
\end{tabular}

The dependent variable, Access to Bank Finance is a dummy variable that equals one if a firm has at least one loan from a bank, zero otherwise. Other variables are defined as previously. Please see table 2 for detailed definitions. Two-tailed P-values are in brackets. *, **, *** represent statistical significance at the $10 \%, 5 \%$ and $1 \%$ levels, respectively. The coefficient estimates are transformed to represent the marginal effects evaluated at the means of the independent variables from the Probit regressions. The marginal effect of a dummy variable is calculated as the discrete change in the expected value of the dependent variable as the dummy variable changes from 0 to 1 . 
Table 5: Tobit regressions on the size of bank finance Variables

Size of Bank Finance

\begin{tabular}{|c|c|c|c|c|}
\hline & {$[1]$} & [2] & [3] & [4] \\
\hline \multicolumn{5}{|l|}{ Performance } \\
\hline \multirow[t]{2}{*}{ Lagged ROS } & 2.542 & 2.585 & 2.480 & 2.478 \\
\hline & {$[0.012]^{* *}$} & {$[0.010]^{* * *}$} & {$[0.011]^{* *}$} & {$[0.011]^{* *}$} \\
\hline \multicolumn{5}{|l|}{ Political Connection } \\
\hline \multirow[t]{2}{*}{ State minority ownership } & & 1.811 & & 1.773 \\
\hline & & {$[0.138]$} & & {$[0.208]$} \\
\hline \multirow[t]{2}{*}{ CEO government official } & & -1.000 & & \\
\hline & & {$[0.284]$} & & \\
\hline \multirow[t]{2}{*}{ Business Connection } & & 0.700 & & \\
\hline & & {$[0.246]$} & & \\
\hline \multicolumn{5}{|l|}{ Managerial Incentives } \\
\hline \multirow[t]{2}{*}{ CEO experience } & & & 0.102 & 0.105 \\
\hline & & & {$[0.028] * *$} & {$[0.023] * *$} \\
\hline \multirow[t]{2}{*}{ CEO ownership } & & & 0.629 & 0.629 \\
\hline & & & [0.241] & [0.239] \\
\hline \multirow[t]{2}{*}{ Annual salary system } & & & 1.838 & 1.880 \\
\hline & & & {$[0.003]^{* * *}$} & {$[0.002]^{* * *}$} \\
\hline \multicolumn{5}{|l|}{ Board Characteristics } \\
\hline \multirow[t]{2}{*}{ Duality } & & & -1.082 & -1.054 \\
\hline & & & {$[0.024]^{* *}$} & {$[0.028]^{* *}$} \\
\hline \multirow[t]{2}{*}{ Independent Director } & & & 0.444 & 0.438 \\
\hline & & & {$[0.003]^{* * *}$} & {$[0.002]^{* * *}$} \\
\hline \multirow[t]{2}{*}{ Board Ownership } & & & 1.285 & 1.234 \\
\hline & & & {$[0.034]^{* *}$} & {$[0.041]^{* *}$} \\
\hline \multicolumn{5}{|l|}{ Other controls } \\
\hline \multirow[t]{2}{*}{ Business Group } & -0.247 & -0.213 & -0.285 & -0.289 \\
\hline & {$[0.633]$} & {$[0.678]$} & {$[0.578]$} & {$[0.572]$} \\
\hline \multirow[t]{2}{*}{ Firm Age } & -0.358 & -0.412 & -0.274 & -0.306 \\
\hline & [0.259] & [0.194] & {$[0.394]$} & {$[0.341]$} \\
\hline \multirow[t]{2}{*}{ Firm Size } & 1.364 & 1.300 & 1.265 & 1.241 \\
\hline & {$[0.000]^{* * *}$} & {$[0.000]^{* * *}$} & {$[0.000]^{* * *}$} & {$[0.000]^{* * *}$} \\
\hline \multirow[t]{2}{*}{ GDP per Capita } & -0.636 & -0.528 & -0.816 & -0.790 \\
\hline & {$[0.331]$} & [0.417] & {$[0.203]$} & {$[0.218]$} \\
\hline \multirow[t]{2}{*}{ City Population } & -0.756 & -0.695 & -0.923 & -0.907 \\
\hline & {$[0.070]^{*}$} & {$[0.093]^{*}$} & {$[0.023] * *$} & {$[0.026] * *$} \\
\hline Industry dummies & Yes & Yes & Yes & Yes \\
\hline Observations & 1689 & 1682 & 1650 & 1650 \\
\hline
\end{tabular}

The dependent variable, Size of Banking Finance is the amount of the line of credit reported by the managers scaled by the firm's total assets. Other variables are defined as previously. Please see table 2 for detailed definitions. Two-tailed P-values are in brackets. *,**,*** represent statistical significance at the $10 \%, 5 \%$ and $1 \%$ levels, respectively. The coefficient estimates are transformed to represent the marginal effects evaluated at the means of the independent variables from the Tobit regressions. The marginal effect of a dummy variable is calculated as the discrete change in the expected value of the dependent variable as the dummy variable changes from 0 to 1 . 
Table 6: Split-sample analysis according to firm size

\begin{tabular}{|c|c|c|c|c|c|c|c|c|}
\hline \multirow[t]{3}{*}{ Variables } & \multicolumn{4}{|c|}{ Access to Bank Finance } & \multicolumn{4}{|c|}{ Size of Bank Finance } \\
\hline & \multicolumn{2}{|c|}{ Large } & \multicolumn{2}{|c|}{ Small } & \multicolumn{2}{|c|}{ Large } & \multicolumn{2}{|c|}{ Small } \\
\hline & [1] & [2] & [3] & [4] & [5] & [6] & [7] & {$[8]$} \\
\hline \multirow[t]{2}{*}{ Lagged ROS } & 0.548 & 0.58 & 0.116 & 0.046 & 12.305 & 13.218 & 10.214 & 8.363 \\
\hline & {$[0.009]^{* * *}$} & {$[0.007]^{* * *}$} & {$[0.670]$} & [0.859] & {$[0.040]^{* *}$} & {$[0.026]^{* *}$} & {$[0.380]$} & {$[0.470]$} \\
\hline \multicolumn{9}{|l|}{ Political connection } \\
\hline \multirow[t]{2}{*}{ State minority ownership } & 0.525 & 0.413 & 0.078 & 0.11 & 11.299 & 9.138 & -4.233 & -0.561 \\
\hline & {$[0.011]^{* *}$} & {$[0.057]^{*}$} & {$[0.863]$} & {$[0.806]$} & {$[0.039] * *$} & {$[0.101]$} & {$[0.822]$} & {$[0.977]$} \\
\hline \multirow[t]{2}{*}{ CEO government official } & 0.07 & & -0.657 & & -1.678 & & -21.445 & \\
\hline & [0.779] & & [0.143] & & [0.808] & & {$[0.191]$} & \\
\hline \multirow[t]{2}{*}{ Business Connection } & 0.16 & & 0.006 & & 3.616 & & 2.941 & \\
\hline & {$[0.150]$} & & {$[0.970]$} & & [0.239] & & {$[0.637]$} & \\
\hline \multicolumn{9}{|l|}{ Board Characteristics } \\
\hline \multirow[t]{2}{*}{ Duality } & & -0.182 & & -0.237 & & -4.154 & & -9.396 \\
\hline & & {$[0.118]$} & & {$[0.150]$} & & {$[0.190]$} & & {$[0.174]$} \\
\hline \multirow[t]{2}{*}{ Independent Director } & & 0.036 & & 0.044 & & 2.479 & & 2.161 \\
\hline & & {$[0.256]$} & & {$[0.362]$} & & {$[0.004]^{* * *}$} & & {$[0.257]$} \\
\hline \multirow[t]{2}{*}{ Board Ownership } & & 0.322 & & 0.136 & & 6.176 & & 11.879 \\
\hline & & {$[0.021]^{* *}$} & & [0.467] & & {$[0.093]^{*}$} & & [0.122] \\
\hline \multicolumn{9}{|l|}{ Managerial incentives } \\
\hline \multirow[t]{2}{*}{ CEO experience } & 0.023 & 0.023 & 0.022 & 0.023 & 0.352 & 0.384 & 0.65 & 0.861 \\
\hline & {$[0.025]^{* *}$} & {$[0.027]^{* *}$} & {$[0.097]^{*}$} & {$[0.082]^{*}$} & {$[0.205]$} & {$[0.169]$} & {$[0.234]$} & {$[0.125]$} \\
\hline \multirow[t]{2}{*}{ CEO ownership } & 0.334 & 0.268 & 0.006 & 0.003 & 7.622 & 6.152 & -1.197 & -3.945 \\
\hline & {$[0.001]^{* * *}$} & {$[0.029]^{* *}$} & [0.964] & [0.982] & {$[0.008]^{* * *}$} & {$[0.059]^{*}$} & [0.810] & [0.478] \\
\hline \multirow[t]{2}{*}{ Annual salary system } & 0.214 & 0.217 & 0.326 & 0.339 & 9.203 & 9.452 & 5.465 & 5.343 \\
\hline & {$[0.038]^{* *}$} & {$[0.039]^{* *}$} & {$[0.047]^{* *}$} & {$[0.041]^{* *}$} & {$[0.001]^{* * *}$} & {$[0.001]^{* * *}$} & {$[0.395]$} & [0.412] \\
\hline \multicolumn{9}{|l|}{ Other controls } \\
\hline \multirow[t]{2}{*}{ Business Group } & -0.036 & -0.067 & -1.232 & -1.325 & 1.482 & -0.015 & -12.729 & -14.44 \\
\hline & [0.724] & {$[0.524]$} & {$[0.002]^{* * *}$} & {$[0.001]^{* * *}$} & [0.604] & [0.996] & [0.174] & [0.137] \\
\hline \multirow[t]{2}{*}{ Firm Age } & -0.018 & -0.004 & -0.184 & -0.191 & -2.178 & -0.927 & -3.721 & -5.023 \\
\hline & [0.786] & [0.956] & {$[0.057]^{*}$} & {$[0.051]^{*}$} & [0.244] & [0.617] & [0.353] & [0.237] \\
\hline \multirow[t]{2}{*}{ Firm Size } & 0.234 & 0.254 & 0.255 & 0.259 & 5.555 & 5.826 & 7.899 & 7.592 \\
\hline & {$[0.000]^{* * *}$} & {$[0.000]^{* * *}$} & {$[0.000]^{* * *}$} & {$[0.000]^{* * *}$} & {$[0.000]^{* * *}$} & {$[0.000]^{* * *}$} & {$[0.001]^{* * *}$} & {$[0.002] * * *$} \\
\hline \multirow[t]{2}{*}{ GDP per Capita } & -0.102 & -0.107 & 0.000 & -0.01 & -3.944 & -3.912 & -2.421 & -3.007 \\
\hline & {$[0.455]$} & {$[0.441]$} & {$[1.000]$} & {$[0.963]$} & [0.294] & [0.296] & {$[0.766]$} & {$[0.716]$} \\
\hline City Population & 0.008 & -0.011 & -0.355 & -0.374 & -1.14 & -1.755 & -15.083 & -15.499 \\
\hline & [0.925] & {$[0.901]$} & {$[0.003]^{* * *}$} & {$[0.002] * * *$} & [0.643] & [0.473] & {$[0.003]^{* * *}$} & {$[0.003]^{* * *}$} \\
\hline Industry dummies & Yes & Yes & Yes & Yes & Yes & Yes & Yes & Yes \\
\hline Observations & 845 & 826 & 871 & 857 & 824 & 806 & 858 & 844 \\
\hline
\end{tabular}

We split the sample firms into large firms (firm size measured by log total assets above the sample median) and small firms (firm size below sample median), and repeat the regressions as specified in Table 4 and Table 5 within each sub-sample. Columns (1), (2), (5) and (6) are based on large firms. Columns (3), (4), (7) and (8) are based on small firms. Columns (1) to (4) are based on Probit models. Columns (5) to (8) are based on Tobit models. Two-tailed P-values are in brackets. *, **, *** represent statistical significance at the $10 \%, 5 \%$ and $1 \%$ levels, respectively. 
Table 7: Split-sample analysis according to industry

\begin{tabular}{|c|c|c|c|c|c|c|c|c|}
\hline \multirow[t]{2}{*}{ Variables } & \multicolumn{4}{|c|}{ Access to Bank Finance } & \multicolumn{4}{|c|}{ Size of Bank Finance } \\
\hline & \multicolumn{2}{|r|}{ Service } & \multicolumn{2}{|c|}{ Manufacturing } & \multicolumn{2}{|c|}{ Service } & \multicolumn{2}{|c|}{ Manufacturing } \\
\hline & {$[1]$} & {$[2]$} & [3] & {$[4]$} & {$[5]$} & {$[6]$} & [7] & {$[8]$} \\
\hline Lagged ROS & $\begin{array}{l}0.250 \\
{[0.540]}\end{array}$ & $\begin{array}{l}0.197 \\
{[0.634]}\end{array}$ & $\begin{array}{l}0.530 \\
{[0.005]^{* * *}}\end{array}$ & $\begin{array}{l}0.529 \\
{[0.005] * * *}\end{array}$ & $\begin{array}{l}0.767 \\
{[0.993]}\end{array}$ & $\begin{array}{l}1.247 \\
{[0.893]}\end{array}$ & $\begin{array}{l}16.455 \\
{[0.006]^{* * *}}\end{array}$ & $\begin{array}{l}17.029 \\
{[0.004]^{* * *}}\end{array}$ \\
\hline \multicolumn{9}{|l|}{ Political connection } \\
\hline State minority ownership & $\begin{array}{l}1.373 \\
{[0.000]^{* * *}}\end{array}$ & $\begin{array}{l}1.330 \\
{[0.001] * * *}\end{array}$ & $\begin{array}{l}0.234 \\
{[0.254]}\end{array}$ & $\begin{array}{l}0.172 \\
{[0.414]}\end{array}$ & $\begin{array}{l}26.458 \\
{[0.006]^{* * *}}\end{array}$ & $\begin{array}{l}22.673 \\
{[0.027]^{* *}}\end{array}$ & $\begin{array}{l}5.696 \\
{[0.351]}\end{array}$ & $\begin{array}{l}4.216 \\
{[0.449]}\end{array}$ \\
\hline CEO government official & $\begin{array}{l}-0.142 \\
{[0.686]}\end{array}$ & & $\begin{array}{l}-0.139 \\
{[0.551]}\end{array}$ & & $\begin{array}{l}-4.500 \\
{[0.658]}\end{array}$ & & $\begin{array}{l}-4.249 \\
{[0.557]}\end{array}$ & \\
\hline Business Connection & $\begin{array}{l}-0.240 \\
{[0.464]}\end{array}$ & & $\begin{array}{l}0.116 \\
{[0.217]}\end{array}$ & & $\begin{array}{l}-5.011 \\
{[0.441]}\end{array}$ & & $\begin{array}{l}3.967 \\
{[0.179]}\end{array}$ & \\
\hline \multicolumn{9}{|l|}{ Managerial incentives } \\
\hline CEO experience & $\begin{array}{l}0.057 \\
{[0.006]^{* * *}}\end{array}$ & $\begin{array}{l}0.058 \\
{[0.005]^{* * *}}\end{array}$ & $\begin{array}{l}0.020 \\
{[0.020]^{* *}}\end{array}$ & $\begin{array}{l}0.021 \\
{[0.016]^{* *}}\end{array}$ & $\begin{array}{l}0.618 \\
{[0.278]}\end{array}$ & $\begin{array}{l}0.684 \\
{[0.250]}\end{array}$ & $\begin{array}{l}0.429 \\
{[0.104]}\end{array}$ & $\begin{array}{l}0.513 \\
{[0.053]^{* *}}\end{array}$ \\
\hline CEO ownership & $\begin{array}{l}0.538 \\
{[0.026]^{* *}}\end{array}$ & $\begin{array}{l}0.433 \\
{[0.088]^{*}}\end{array}$ & $\begin{array}{l}0.166 \\
{[0.049]^{* *}}\end{array}$ & $\begin{array}{l}0.154 \\
{[0.115]}\end{array}$ & $\begin{array}{l}10.944 \\
{[0.037]^{* *}}\end{array}$ & $\begin{array}{l}7.373 \\
{[0.249]}\end{array}$ & $\begin{array}{l}3.326 \\
{[0.206]}\end{array}$ & $\begin{array}{l}2.347 \\
{[0.427]}\end{array}$ \\
\hline Annual salary system & $\begin{array}{l}0.417 \\
{[0.099]^{*}}\end{array}$ & $\begin{array}{l}0.422 \\
{[0.106]}\end{array}$ & $\begin{array}{l}0.231 \\
{[0.013]^{* *}}\end{array}$ & $\begin{array}{l}0.235 \\
{[0.012]^{* *}}\end{array}$ & $\begin{array}{l}7.079 \\
{[0.260]}\end{array}$ & $\begin{array}{l}5.480 \\
{[0.399]}\end{array}$ & $\begin{array}{l}8.637 \\
{[0.002]^{* * *}}\end{array}$ & $\begin{array}{l}8.722 \\
{[0.002] * * *}\end{array}$ \\
\hline \multicolumn{9}{|l|}{ Board Characteristics } \\
\hline Duality & & $\begin{array}{l}-0.215 \\
{[0.437]}\end{array}$ & & $\begin{array}{l}-0.243 \\
{[0.016]^{* *}}\end{array}$ & & $\begin{array}{l}0.057 \\
{[0.993]}\end{array}$ & & $\begin{array}{l}-7.204 \\
{[0.020]^{* *}}\end{array}$ \\
\hline Independent Director & & $\begin{array}{l}-0.063 \\
{[0.522]}\end{array}$ & & $\begin{array}{l}0.047 \\
{[0.103]}\end{array}$ & & $\begin{array}{l}0.972 \\
{[0.562]}\end{array}$ & & $\begin{array}{l}2.469 \\
{[0.004] * * *}\end{array}$ \\
\hline Board Ownership & & $\begin{array}{l}0.367 \\
{[0.230]}\end{array}$ & & $\begin{array}{l}0.194 \\
{[0.096]^{*}}\end{array}$ & & $\begin{array}{l}8.792 \\
{[0.245]}\end{array}$ & & $\begin{array}{l}6.019 \\
{[0.084]^{*}}\end{array}$ \\
\hline \multicolumn{9}{|l|}{ Other controls } \\
\hline Business Group & $\begin{array}{l}-0.241 \\
{[0.369]}\end{array}$ & $\begin{array}{l}-0.146 \\
{[0.606]}\end{array}$ & $\begin{array}{l}-0.146 \\
{[0.123]}\end{array}$ & $\begin{array}{l}-0.200 \\
{[0.040]^{* *}}\end{array}$ & $\begin{array}{l}11.795 \\
{[0.043]^{* *}}\end{array}$ & $\begin{array}{l}12.785 \\
{[0.037]^{* *}}\end{array}$ & $\begin{array}{l}-1.270 \\
{[0.676]}\end{array}$ & $\begin{array}{l}-3.477 \\
{[0.261]}\end{array}$ \\
\hline Firm Age & $\begin{array}{l}0.077 \\
{[0.634]}\end{array}$ & $\begin{array}{l}0.058 \\
{[0.772]}\end{array}$ & $\begin{array}{l}-0.100 \\
{[0.093]^{*}}\end{array}$ & $\begin{array}{l}-0.178 \\
{[0.199]}\end{array}$ & $\begin{array}{l}2.895 \\
{[0.381]}\end{array}$ & $\begin{array}{l}4.040 \\
{[0.249]}\end{array}$ & $\begin{array}{l}-3.831 \\
{[0.042]^{* *}}\end{array}$ & $\begin{array}{l}-2.994 \\
{[0.115]}\end{array}$ \\
\hline Firm Size & $\begin{array}{l}0.275 \\
{[0.000]^{* * *}}\end{array}$ & $\begin{array}{l}0.277 \\
{[0.000]^{* * *}}\end{array}$ & $\begin{array}{l}0.232 \\
{[0.000]^{* * *}}\end{array}$ & $\begin{array}{l}0.241 \\
{[0.000] * * *}\end{array}$ & $\begin{array}{l}4.551 \\
{[0.001]^{* * *}}\end{array}$ & $\begin{array}{l}4.682 \\
{[0.001] * * *}\end{array}$ & $\begin{array}{l}6.482 \\
{[0.000]^{* * *}}\end{array}$ & $\begin{array}{l}6.690 \\
{[0.000]^{* * *}}\end{array}$ \\
\hline GDP per Capita & $\begin{array}{l}-0.529 \\
{[0.112]}\end{array}$ & $\begin{array}{l}-0.530 \\
{[0.109]}\end{array}$ & $\begin{array}{l}-0.054 \\
{[0.649]}\end{array}$ & $\begin{array}{l}-0.058 \\
{[0.620]}\end{array}$ & $\begin{array}{l}-19.937 \\
{[0.011]^{* *}}\end{array}$ & $\begin{array}{l}-19.842 \\
{[0.016]^{* *}}\end{array}$ & $\begin{array}{l}-2.059 \\
{[0.578]}\end{array}$ & $\begin{array}{l}-2.006 \\
{[0.587]}\end{array}$ \\
\hline City Population & $\begin{array}{l}-0.005 \\
{[0.977]}\end{array}$ & $\begin{array}{l}-0.002 \\
{[0.992]}\end{array}$ & $\begin{array}{l}-0.133 \\
{[0.065]^{*}}\end{array}$ & $\begin{array}{l}-0.155 \\
{[0.035]^{* *}}\end{array}$ & $\begin{array}{l}-4.730 \\
{[0.284]}\end{array}$ & $\begin{array}{l}-4.489 \\
{[0.331]}\end{array}$ & $\begin{array}{l}-4.666 \\
{[0.049]^{* *}}\end{array}$ & $\begin{array}{l}-5.131 \\
{[0.030]^{* *}}\end{array}$ \\
\hline Industry dummies & Yes & Yes & Yes & Yes & Yes & Yes & Yes & Yes \\
\hline Observations & 356 & 348 & 1360 & 1335 & 350 & 343 & 1332 & 1307 \\
\hline
\end{tabular}

We split the sample firms into service firms and manufacturing firms, and repeat the regressions as specified in Table 4 and Table 5 within each sub-sample. Columns (1), (2), (5) and (6) are based on service firms. Columns (3), (4), (7) and (8) are based on manufacturing firms. Columns (1) to (4) are based on Probit models. Columns (5) to (8) are based on Tobit models. Two-tailed $\mathrm{P}$-values are in brackets.*,**,*** represent statistical significance at the $10 \%, 5 \%$ and $1 \%$ levels, respectively. 
Table 8: Probit regressions on the access to bank finance with marketization index

\begin{tabular}{|c|c|c|c|c|c|}
\hline \multirow[t]{2}{*}{ Variables } & \multicolumn{5}{|c|}{ Access to Bank Finance } \\
\hline & [1] & [2] & [3] & [4] & [5] \\
\hline \multirow{2}{*}{ Lagged ROS } & 0.419 & 0.421 & 0.412 & 0.439 & 0.409 \\
\hline & {$[0.011]^{* *}$} & {$[0.011]^{* *}$} & {$[0.013]^{* *}$} & {$[0.008]^{* * *}$} & {$[0.013]^{* *}$} \\
\hline \multirow[t]{2}{*}{ State minority ownership } & 0.377 & 0.361 & 0.361 & 0.388 & 0.367 \\
\hline & {$[0.046]^{* *}$} & {$[0.058]^{*}$} & {$[0.058]^{*}$} & {$[0.039]^{* *}$} & {$[0.053]^{*}$} \\
\hline \multirow[t]{2}{*}{ CEO experience } & 0.025 & 0.025 & 0.026 & 0.024 & 0.025 \\
\hline & {$[0.002]^{* * *}$} & {$[0.002]^{* * *}$} & {$[0.001] * * *$} & {$[0.003]^{* * *}$} & {$[0.002]^{* * *}$} \\
\hline \multirow[t]{2}{*}{ CEO ownership } & 0.181 & 0.180 & 0.182 & 0.175 & 0.184 \\
\hline & {$[0.047]^{* *}$} & {$[0.047]^{* *}$} & {$[0.046]^{* *}$} & {$[0.053]^{*}$} & {$[0.043]^{* *}$} \\
\hline \multirow[t]{2}{*}{ Annual salary system } & 0.262 & 0.260 & 0.273 & 0.251 & 0.271 \\
\hline & {$[0.003]^{* * *}$} & {$[0.003]^{* * *}$} & {$[0.002]^{* * *}$} & {$[0.005]^{* * *}$} & {$[0.002] * * *$} \\
\hline \multirow[t]{2}{*}{ Duality } & -0.215 & -0.216 & -0.207 & -0.220 & -0.210 \\
\hline & {$[0.021]^{* *}$} & {$[0.020]^{* *}$} & {$[0.026]^{* *}$} & {$[0.018]$} & {$[0.025]^{* *}$} \\
\hline \multirow[t]{2}{*}{ Independent Director } & 0.036 & 0.036 & 0.035 & 0.037 & 0.035 \\
\hline & {$[0.174]$} & {$[0.171]$} & {$[0.182]$} & {$[0.160]$} & {$[0.184]$} \\
\hline \multirow[t]{2}{*}{ Board Ownership } & 0.210 & 0.209 & 0.216 & 0.205 & 0.213 \\
\hline & {$[0.051]^{*}$} & {$[0.052]^{*}$} & {$[0.046]^{* *}$} & {$[0.056]^{*}$} & {$[0.048]^{* *}$} \\
\hline \multicolumn{6}{|l|}{ Other Controls } \\
\hline \multirow[t]{2}{*}{ Business Group } & -0.201 & -0.202 & -0.196 & -0.201 & -0.200 \\
\hline & {$[0.026]^{* *}$} & {$[0.026]^{* *}$} & {$[0.031]^{* *}$} & {$[0.027]^{* *}$} & {$[0.027]^{* *}$} \\
\hline \multirow[t]{2}{*}{ Firm Age } & -0.053 & -0.052 & -0.058 & -0.049 & -0.057 \\
\hline & {$[0.341]$} & [0.347] & {$[0.304]$} & [0.379] & [0.308] \\
\hline \multirow[t]{2}{*}{ Firm Size } & 0.246 & 0.245 & 0.253 & 0.239 & 0.251 \\
\hline & {$[0.000]^{* * *}$} & {$[0.000]^{* * *}$} & {$[0.000]^{* * *}$} & {$[0.000]^{* * *}$} & {$[0.000]^{* * *}$} \\
\hline \multirow[t]{2}{*}{ GDP per Capita } & -0.108 & -0.125 & -0.034 & -0.154 & -0.032 \\
\hline & {$[0.344]$} & {$[0.315]$} & {$[0.796]$} & {$[0.176]$} & {$[0.813]$} \\
\hline \multirow{2}{*}{ City Population } & -0.120 & -0.120 & -0.134 & -0.123 & -0.135 \\
\hline & {$[0.083]^{*}$} & {$[0.078]^{*}$} & {$[0.054]^{*}$} & {$[0.068]^{*}$} & {$[0.051]^{*}$} \\
\hline \multirow[t]{2}{*}{ Government and Market } & 0.012 & & & & \\
\hline & {$[0.776]$} & & & & \\
\hline \multirow[t]{2}{*}{ Development of Non-state Sector } & & 0.007 & & & \\
\hline & & {$[0.637]$} & & & \\
\hline Development of Product Market & & & $\begin{array}{l}-0.036 \\
{[0.227]}\end{array}$ & & \\
\hline \multirow[t]{2}{*}{ Banking Sector Marketization } & & & & 0.037 & \\
\hline & & & & {$[0.029]^{* *}$} & \\
\hline \multirow[t]{2}{*}{ Legal Environment } & & & & & -0.023 \\
\hline & & & & & {$[0.320]$} \\
\hline Industry dummies & Yes & Yes & Yes & Yes & Yes \\
\hline Observations & 1683 & 1683 & 1683 & 1683 & 1683 \\
\hline
\end{tabular}

We repeat the regressions as specified in Table 4 with five categories of marketization indices. Each index enters into regression column by column separately. The remaining variables are defined as previously. The detailed definitions can be found in table 2 . Two-tailed P-values are in brackets. *, **, *** represent statistical significance at the $10 \%, 5 \%$ and $1 \%$ levels, respectively. 
Table 9: Tobit regressions on the size of bank finance with marketization index

\begin{tabular}{|c|c|c|c|c|c|}
\hline Variables & & & of Bank Fi & & \\
\hline & [1] & [2] & [3] & [4] & [5] \\
\hline Lagged ROS & 13.295 & 13.317 & 13.069 & 13.907 & 13.083 \\
\hline & {$[0.011]^{* *}$} & {$[0.011]^{* *}$} & {$[0.012]^{* *}$} & {$[0.008]^{* * *}$} & {$[0.012]^{* *}$} \\
\hline State minority ownership & 8.218 & 8.268 & 7.792 & 8.476 & 7.926 \\
\hline & [0.132] & {$[0.130]$} & {$[0.155]$} & [0.119] & {$[0.147]$} \\
\hline CEO experience & 0.549 & 0.546 & 0.560 & 0.518 & 0.558 \\
\hline & {$[0.026]^{* *}$} & {$[0.027]^{* *}$} & {$[0.023]^{* *}$} & {$[0.036]^{* *}$} & {$[0.024] * *$} \\
\hline CEO ownership & 3.146 & 3.154 & 3.256 & 2.945 & 3.272 \\
\hline & [0.247] & {$[0.246]$} & [0.232] & [0.277] & [0.229] \\
\hline Annual salary system & 8.587 & 8.564 & 8.952 & 8.060 & 8.905 \\
\hline & {$[0.001] * * *$} & {$[0.001] * * *$} & {$[0.001]^{* * *}$} & {$[0.002]^{* * *}$} & {$[0.001]^{* * *}$} \\
\hline Duality & -5.951 & -5.997 & -5.828 & -6.077 & -5.876 \\
\hline & {$[0.036]^{* *}$} & {$[0.035]^{* *}$} & {$[0.040]^{* *}$} & {$[0.032]^{* *}$} & {$[0.039]^{* *}$} \\
\hline Independent Director & 2.333 & 2.337 & 2.312 & 2.379 & 2.314 \\
\hline & {$[0.003]^{* * *}$} & {$[0.003]^{* * *}$} & {$[0.003]^{* * *}$} & {$[0.002]^{* * *}$} & {$[0.003]^{* * *}$} \\
\hline Board Ownership & 6.448 & 6.415 & 6.576 & 6.309 & 6.540 \\
\hline & {$[0.044]^{* *}$} & {$[0.045]^{* *}$} & {$[0.046]^{* *}$} & {$[0.048]^{* *}$} & {$[0.041]^{* *}$} \\
\hline Other controls & & & & & \\
\hline Business Group & -1.488 & -1.535 & -1.513 & -1.519 & -1.555 \\
\hline & [0.597] & {$[0.585]$} & [0.591] & {$[0.588]$} & {$[0.580]$} \\
\hline Firm Age & -1.558 & -1.543 & -1.656 & -1.444 & -1.635 \\
\hline & {$[0.360]$} & [0.364] & [0.331] & {$[0.396]$} & [0.337] \\
\hline Firm Size & 6.457 & 6.440 & 6.625 & 6.267 & 6.585 \\
\hline & {$[0.000] * * *$} & {$[0.000]^{* * *}$} & {$[0.000]^{* * *}$} & {$[0.000]^{* * *}$} & {$[0.000]^{* * *}$} \\
\hline GDP per Capita & -4.995 & -5.768 & -3.510 & -6.517 & -3.863 \\
\hline & {$[0.151]$} & {$[0.118]$} & {$[0.353]$} & {$[0.060]^{*}$} & {$[0.332]$} \\
\hline City Population & -4.527 & -4.645 & -4.893 & -4.903 & -4.851 \\
\hline & {$[0.037]^{* *}$} & {$[0.031]^{* *}$} & {$[0.024]^{* *}$} & {$[0.022]^{* *}$} & {$[0.026]^{* *}$} \\
\hline Government and Market & 1.366 & & & & \\
\hline & {$[0.298]$} & & & & \\
\hline Development of Non-state Sector & & 0.476 & & & \\
\hline & & [0.279] & & & \\
\hline Development of Product Market & & & -0.341 & & \\
\hline & & & {$[0.686]$} & & \\
\hline Banking Sector Marketization & & & & 1.529 & \\
\hline & & & & {$[0.003]^{* * *}$} & \\
\hline Legal Environment & & & & & -0.102 \\
\hline & & & & & [0.879] \\
\hline Industry dummies & Yes & Yes & Yes & Yes & Yes \\
\hline Observations & 1650 & 1650 & 1650 & 1650 & 1650 \\
\hline
\end{tabular}

We repeat the regressions as specified in Table 5 with five categories of marketization indices. Each index enters into regression column by column separately. The remaining variables are defined as previously. The detailed definitions can be found in table 2. Two-tailed P-values are in brackets. *, **, *** represent statistical significance at the $10 \%, 5 \%$ and $1 \%$ levels, respectively. 
Table 10: Split sample analysis according to regional banking marketization index

\begin{tabular}{|c|c|c|c|c|c|c|c|c|}
\hline \multirow[t]{3}{*}{ Variables } & \multicolumn{4}{|c|}{ Access to Bank Finance } & \multicolumn{4}{|c|}{ Size of Bank Finance } \\
\hline & \multicolumn{2}{|c|}{ Poor Bank Marketization } & \multicolumn{2}{|c|}{ Good Bank Marketization } & \multicolumn{2}{|c|}{ Poor Bank Marketization } & \multicolumn{2}{|c|}{ Good Bank Marketization } \\
\hline & [1] & {$[2]$} & {$[3]$} & {$[4]$} & {$[5]$} & [6] & {$[7]$} & {$[8]$} \\
\hline Lagged ROS & $\begin{array}{l}0.419 \\
{[0.139]}\end{array}$ & $\begin{array}{l}0.425 \\
{[0.139]}\end{array}$ & $\begin{array}{l}0.447 \\
{[0.015]^{* *}}\end{array}$ & $\begin{array}{l}0.474 \\
{[0.012]^{* *}}\end{array}$ & $\begin{array}{l}11.12 \\
{[0.187]}\end{array}$ & $\begin{array}{l}11.958 \\
{[0.186]}\end{array}$ & $\begin{array}{l}14.089 \\
{[0.002]^{* * *}}\end{array}$ & $\begin{array}{l}14.746 \\
{[0.000]^{* * * *}}\end{array}$ \\
\hline \multicolumn{9}{|l|}{ Political Connection } \\
\hline State minority ownership & $\begin{array}{l}0.685 \\
{[0.029]^{* *}}\end{array}$ & $\begin{array}{l}0.53 \\
{[0.072]^{*}}\end{array}$ & $\begin{array}{l}0.442 \\
{[0.129]}\end{array}$ & $\begin{array}{l}0.406 \\
{[0.169]}\end{array}$ & $\begin{array}{l}22.104 \\
{[0.003]^{* * *}}\end{array}$ & $\begin{array}{l}20.042 \\
{[0.009]^{* * *}}\end{array}$ & $\begin{array}{l}7.361 \\
{[0.311]}\end{array}$ & $\begin{array}{l}5.646 \\
{[0.408]}\end{array}$ \\
\hline CEO gov. official & $\begin{array}{l}-0.181 \\
{[0.544]}\end{array}$ & & $\begin{array}{l}-0.098 \\
{[0.732]}\end{array}$ & & $\begin{array}{l}-2.526 \\
{[0.822]}\end{array}$ & & $\begin{array}{l}-5.443 \\
{[0.516]}\end{array}$ & \\
\hline Business Connection & $\begin{array}{l}0.296 \\
{[0.062]^{*}}\end{array}$ & & $\begin{array}{l}-0.031 \\
{[0.836]}\end{array}$ & & $\begin{array}{l}6.643 \\
{[0.129]}\end{array}$ & & $\begin{array}{l}0.509 \\
{[0.824]}\end{array}$ & \\
\hline \multicolumn{9}{|l|}{ Managerial incentives } \\
\hline CEO experience & $\begin{array}{l}0.03 \\
{[0.019]^{* *}}\end{array}$ & $\begin{array}{l}0.034 \\
{[0.005] * * *}\end{array}$ & $\begin{array}{l}0.026 \\
{[0.034]^{* *}}\end{array}$ & $\begin{array}{l}0.025 \\
{[0.035]^{* *}}\end{array}$ & $\begin{array}{l}0.749 \\
{[0.018]^{* *}}\end{array}$ & $\begin{array}{l}1.038 \\
{[0.001]^{* * *}}\end{array}$ & $\begin{array}{l}0.481 \\
{[0.193]}\end{array}$ & $\begin{array}{l}0.479 \\
{[0.166]}\end{array}$ \\
\hline CEO ownership & $\begin{array}{l}0.426 \\
{[0.021]^{* *}}\end{array}$ & $\begin{array}{l}0.466 \\
{[0.083]^{*}}\end{array}$ & $\begin{array}{l}0.084 \\
{[0.565]}\end{array}$ & $\begin{array}{l}0.036 \\
{[0.827]}\end{array}$ & $\begin{array}{l}12.141 \\
{[0.010]^{* * *}}\end{array}$ & $\begin{array}{l}14.468 \\
{[0.073]^{*}}\end{array}$ & $\begin{array}{l}0.672 \\
{[0.872]}\end{array}$ & $\begin{array}{l}-2.044 \\
{[0.626]}\end{array}$ \\
\hline Annual salary system & $\begin{array}{l}0.12 \\
{[0.534]^{* *}}\end{array}$ & $\begin{array}{l}0.112 \\
{[0.558]}\end{array}$ & $\begin{array}{l}0.338 \\
{[0.000] * * *}\end{array}$ & $\begin{array}{l}0.336 \\
{[0.003]^{* * *}}\end{array}$ & $\begin{array}{l}0.697 \\
{[0.902]}\end{array}$ & $\begin{array}{l}0.475 \\
{[0.926]}\end{array}$ & $\begin{array}{l}11.355 \\
{[0.000]^{* * *}}\end{array}$ & $\begin{array}{l}11.199 \\
{[0.001]^{* * *}}\end{array}$ \\
\hline \multicolumn{9}{|l|}{ Board Structure } \\
\hline Duality & & $\begin{array}{l}-0.216 \\
{[0.017]^{* *}}\end{array}$ & & $\begin{array}{l}-0.215 \\
{[0.005]^{* * *}}\end{array}$ & & $\begin{array}{l}-7.515 \\
{[0.164]}\end{array}$ & & $\begin{array}{l}-4.766 \\
{[0.067]^{*}}\end{array}$ \\
\hline Independent Director & & $\begin{array}{l}-0.005 \\
{[0.815]}\end{array}$ & & $\begin{array}{l}0.053 \\
{[0.158]}\end{array}$ & & $\begin{array}{l}1.371 \\
{[0.059] *}\end{array}$ & & $\begin{array}{l}2.758 \\
{[0.006] * * *}\end{array}$ \\
\hline Board Ownership & & $\begin{array}{l}0.093 \\
{[0.668]}\end{array}$ & & $\begin{array}{l}0.251 \\
{[0.053]^{*}}\end{array}$ & & $\begin{array}{l}4.389 \\
{[0.474]}\end{array}$ & & $\begin{array}{l}6.922 \\
{[0.000]^{*} * *}\end{array}$ \\
\hline \multicolumn{9}{|l|}{ Other controls } \\
\hline Business Group & $\begin{array}{l}-0.481 \\
{[0.007]^{* * *}}\end{array}$ & $\begin{array}{l}-0.454 \\
{[0.003]^{* * *}}\end{array}$ & $\begin{array}{l}-0.01 \\
{[0.913]}\end{array}$ & $\begin{array}{l}-0.088 \\
{[0.204]}\end{array}$ & $\begin{array}{l}-6.724 \\
{[0.376]}\end{array}$ & $\begin{array}{l}-7.039 \\
{[0.337]}\end{array}$ & $\begin{array}{l}3.731 \\
{[0.089] *}\end{array}$ & $\begin{array}{l}-20.588 \\
{[0.046]^{* *}}\end{array}$ \\
\hline Firm Age & $\begin{array}{l}-0.077 \\
{[0.355]}\end{array}$ & $\begin{array}{l}-0.08 \\
{[0.279]}\end{array}$ & $\begin{array}{l}-0.076 \\
{[0.092]^{*}}\end{array}$ & $\begin{array}{l}-0.056 \\
{[0.329]}\end{array}$ & $\begin{array}{l}-0.789 \\
{[0.774]}\end{array}$ & $\begin{array}{l}-0.499 \\
{[0.859]}\end{array}$ & $\begin{array}{l}-3.342 \\
{[0.000] * * *}\end{array}$ & $\begin{array}{l}-2.512 \\
{[0.009]^{* * * *}}\end{array}$ \\
\hline Firm Size & $\begin{array}{l}0.366 \\
{[0.000] * * *}\end{array}$ & $\begin{array}{l}0.37 \\
{[0.000] * * *}\end{array}$ & $\begin{array}{l}0.175 \\
{[0.000] * * *}\end{array}$ & $\begin{array}{l}0.184 \\
{[0.000]^{* * *}}\end{array}$ & $\begin{array}{l}10.314 \\
{[0.001]^{* * *}}\end{array}$ & $\begin{array}{l}10.965 \\
{[0.000]^{* * *}}\end{array}$ & $\begin{array}{l}4.412 \\
{[0.000] * * *}\end{array}$ & $\begin{array}{l}4.361 \\
{[0.000] * * * *}\end{array}$ \\
\hline GDP per Capita & {$[0.034]^{* *}$} & $\begin{array}{l}-0.431 \\
{[0.077]^{*}}\end{array}$ & $\begin{array}{l}0.117 \\
{[0.341]}\end{array}$ & $\begin{array}{l}0.126 \\
{[0.353]}\end{array}$ & $\begin{array}{l}-29.935 \\
{[0.007] * * *}\end{array}$ & $\begin{array}{l}-28.439 \\
{[0.010]^{* * *}}\end{array}$ & $\begin{array}{l}3.839 \\
{[0.430]}\end{array}$ & $\begin{array}{l}4.302 \\
{[0.357]}\end{array}$ \\
\hline City Population & $\begin{array}{l}-0.342 \\
{[0.051]^{*}}\end{array}$ & $\begin{array}{l}-0.335 \\
{[0.096]^{*}}\end{array}$ & $\begin{array}{l}0.103 \\
{[0.206]}\end{array}$ & $\begin{array}{l}0.915 \\
{[0.250]}\end{array}$ & $\begin{array}{l}-7.618 \\
{[0.184]}\end{array}$ & $\begin{array}{l}-8.001 \\
{[0.222]}\end{array}$ & $\begin{array}{l}2.282 \\
{[0.392]}\end{array}$ & $\begin{array}{l}2.127 \\
{[0.356]}\end{array}$ \\
\hline Industry dummies & Yes & Yes & Yes & Yes & Yes & Yes & Yes & Yes \\
\hline Observations & 693 & 686 & 1023 & 997 & 678 & 672 & 1004 & 978 \\
\hline
\end{tabular}

We split the sample firms into firms located in areas with a low degree of regional banking marketization index (marketization index $<=5)$ and firms located in areas with a high degree of regional banking marketization index (marketization index >=5). Detailed definitions of the variables can be found in table 2 . Two-tailed P-values are in brackets.*,**,*** represent statistical significance at the $10 \%, 5 \%$ and $1 \%$ levels, respectively. 